Józef M. DOEĘGA*

\title{
Filozofia sozologii systemowej
}

\section{Wprowadzenie}

Artykuł zawiera problematykę filozofii sozologii systemowej skupiona wokół sześciu zagadnień. W pierwszym - pod tytułem nota $\mathbf{z}$ historii sozologii przedstawiono historię tej nauki, jej prekursorów, międzynarodowe i polskie uwarunkowania powstania oraz perspektywy jej rozwoju. W drugim - koncepcja sozologii systemowej - ukazuje się podstawowe założenia tego ujęcia, a mianowicie: wyjaśnienie podstawowych terminów, syntetyczne ujęcie koncepcji sozologii empirycznej, humanistycznej, filozoficznej oraz charakterystykę systemowej koncepcji sozologii. W trzecim - zagadnienia epistemologiczne wyznaczają treść tego punktu, w którym analizuje się pojęcie sozologii, podejmuje próbę zdefiniowania tej nauki, określenia przedmiotu jej badań. W czwartym podejmuje się zagadnienia metodologiczne sozologii systemowej, gdzie omawia się metody empiryczne, humanistyczne, filozoficzne i systemowe $w$ sozologii systemowej. Natomiast $w$ piątym - zaprezentowano główną problematykę sozologii systemowej i specyfikę badań z zakresu tej nauki.

\section{Kilka uwag $\mathrm{z}$ historii sozologii}

Historyczne uwarunkowania powstania sozologii i sozologii systemowej stanowią treść rozdziału pierwszego. Treść ta jest pewnego rodzaju spojrzeniem na uwarunkowania światowe i narodowe (tu polskie), które zadecydowały o powstaniu tej nauki oraz systemowej koncepcji sozologii. Przypominamy tutaj pierwszych uczonych, którzy swoją pracą badawczą i społeczną stworzyli odpowiednie warunki powstania nauki, która zajmuje się ochroną środowiska. Zasygnalizujemy również proces tworzenia i perspektywy rozwoju sozologii systemowej.

\footnotetext{
Instytut Ekologii i Bioetyki UKSW w Warszawie.
} 


\section{1. Prapoczątki nauki o ochronie środowiska}

Prapoczątków nauki o ochronie środowiska (sozologii) należy szukać nie na przełomie XIX i XX wieku, ale znacznie wcześniej. Uważamy, że zaczątków ochrony przyrody jako środowiska życia człowieka należy się dopatrywać już $w$ najdawniejszych źródłach związanych $z$ wierzeniami religijnymi. Źródła takie stwierdza się nie tylko wśród plemion zamieszkałych na terenach naszej ojczyzny ${ }^{1}$, ale także wśród narodów na całej $z^{2 i e m i}{ }^{2}$, a ich przedmiotem są drzewa, zwierzęta, różne osobliwości przyrody. Te pierwotne motywy ochrony przyrody dotyczyły małego zakresu obiektów przyrodniczych, ale skutecznie zabezpieczały je przed gospodarczą działalnością człowieka.

Wraz z rozwojem cywilizacji, ekspansją techniczną ingerującą w świat przyrody i eksplozją demograficzną zaczęto zdawać sobie sprawę z potrzeby tworzenia prawnych podstaw ochrony przyrody. Za Władysławem Szaferem ${ }^{3}$ przytoczymy dla przykładu niektóre zarządzenia ochrony przyrody w Europie, konkretnie wybranych gatunków zwierząt i roślin, natomiast z czsów starożytnnych wspominamy Chiny, Indie i Cesarstwo Rzymskie.

1. W Chinach za panowania dynastii Czou (XII-III w. p.n.e.) wprowadzono próbę ochrony lasów, ustanawiając spejalny urząd leśnika ${ }^{4}$;

2. Z Indii znane jest orędzie króla Asioki, panującego w latach ok. 269$232 \mathrm{r}$ p. n. e., dotyczące ochrony przede wszystkim lasów, zwierząt i $\mathrm{ryb}^{5}$;

3. Cesarz Rzymski Hadrian (76-138 n. e.) wprowadził ochronę lasów libańskich ;

4. Zarządzenie ochrony ptaków śpiewających wydane $w$ Zurychu $w$ 1535 roku ze względu na ich użyteczność w tępieniu szkodników w sadach i lasach oraz $z$ racji estetycznych;

5. Król Danii Chrystian V wydał w 1671 roku zakaz wycinania lasów w południowej części swego królestwa;

6. Car Piotr I wydał w latach 1703, 1714 i 1722 zarządzenia ochrony lasów;

1 Por. W. SZEFER, Dzieje ochrony przyrody w Polsce i w innych krajach, w: Ochrona przyrodniczego środowiska czlowieka, pod red. W.Szafera, Warszawa 1973, 13-15

2 Por. M. ELIADE, Traktat o historii religii, thum. J. Wierusz-Kowalski, Warszawa 1966, 262320; tenże Historia wierzeń religijnych, thum. T. Tokarski, Warszawa 1988, 30, 54, 117-118, 156, 268, 295; W. ANTONIEWICZ, Religie dawnych Stowian, w: Religie w przssztości $i$ dobie wspótczesnej, tłum. B.Kupis, Warszawa 1975, 82-84, 416-418, 568-517.

3 W. SZAFER, Dzieje ochrony przyrody, 13-15; Leksykon ochrony środowiska prawo i polityka, pod red. H. Lisicka, I. Macek, W. Radecki, TNPOC, Wrocław 1999, 23-28.

4 Por. K.R. MAZURSKI, Podstawy sozologii, Wroclaw 1998, 253; T. •BIKOWSKI, ChinyHistoria w: WEP, t. 2, 433-442; Leksykon ochrony środow iska prawo i polityka, 22.

5 Por. Leksykon ochrony środowiska prawo i polityka, 22.

6 Por. K.R. MAZURSKI, Podstaw'y sozologii, 253 
7. Statuty Kazimierza Wielkiego z drugiej połowy XIV wieku zabraniały kradzieży wielu obiektów przyrodniczych w lasach, jeziorach, rzekach;

8. Król Polski Władysław Jagiełło znacznie ograniczył prawo łowieckie;

9. Król Polski Zygmunt I w I Statucie Litewskim z roku 1529 zawarł rozporządzenie o ochronie bobra (pod ochroną byl już w czasach Bolesława Chrobrego), (II Statut Litewski z 1566 r i III Statut Litewski z $1588 \mathrm{r}$ );

10. Ustawa włóczna z 1557 r. wprowadziła ochronę grubego zwierza; 9. Król Polski Zygmunt III w 1597 roku wydał zarządzenie ochrony tura (zarządzenia to ukazało się za późno, gatunku tego już nie uratowano);

11. Carowa Katarzyna II w 1773 roku zarządziła ochronę łosia w Rosji;

12. Uniwersał leśny Stanisława Augusta Poniatowskiego z 1778 r.;

13. W końcu XV wieku w Norymberdze wydano zakaz zabijania skowronków;

14. W połowie XVIII wieku w Munster zakazano masowego niszczenia kwiatów wiosennych w okresie świąt wielkanocnych.

Wymienione zarządzenia i rozporządzenia wyrażają naturalną tendencję człowieka do ochrony zagrożonych gatunków zwierząt i roślin. Dopiero w XIX wieku przyrodnicy, geografowie i geolodzy położyli fundament pod badania naukowe $z$ zakresu ochrony przyrody. Działalność ich skupiła się na naukowej inwentaryzacji obiektów przyrody oraz znalezieniu skutecznych metod ochrony ginących gatunków istot żywych. Ogólnie można stwierdzić, że prace naukowe dotyczące ochrony przyrody są prowadzone od stu lat. Natomiast dopiero w latach sześćdziesiątych i osiemdziesiątych $X X$ wieku podjęto efektywne próby sprecyzowania epistemologicznego i metodologicznego statusu tej nauki. Współcześnie, na przełomie wieków XX i XXI obserwujemy jednak wysiłki podejmowane w celu zmodyfikowania przedmiotu badań i wypracowania metod sozologii systemowej.

\section{2. $\mathrm{Z}$ historii sozologii w Polsce}

Historia sozologii $w$ Polsce jest związana $z$ działalnością i pracą naukową wielu przyrodników w XIX i XX wieku. Z ich grona przypominamy tutaj w porządku chronologicznym tylko nielicznych - tych, których wkład w powstanie nauki o ochronie naturalnego środowiska człowieka wydaje się szczególnie znaczący.

1. Marian Raciborski ${ }^{7}$ (1863-1917) urodził się w Brzostowie koło o Opatowa, zmarł w Zakopanem. Był twórca polskiej szkoły fitogeograficz-

7 Marian Raciborski (1863-1917), botanik, uczeń między innymi E.Strasburgera w Bonn i K.Goebla w Monachium. Od 1900 roku był członkiem Akademii Umiejętności, w latach 
nej, opracował pierwszą mapę geobotaniczną Polski, należał do inicjatorów ruchu ochrony przyrody w naszej ojczyźnie.

M. Raciborski jako jeden $\mathrm{z}$ pierwszych w Europie prowadził w roku akademickim 1913/1914 wykłady o ochronie przyrody pod tytułem: "Zabytki przyrody". Wykłady te były poświęcone następującym zagadnieniem:

- „ochrona przyrody" jako nowa dziedzina badań na uniwersytetach polskich i światowych;

- analiza pojęcia "zabytki przyrody", "pomnik przyrody";

- zarys historii ochrony przyrody;

- niszczenie przyrody przez działalność gospodarczą człowieka;

- motywy i cele ochrony przyrody;

- potrzeba ochrony rodzimego krajobrazu.

Zagadnienia te tworzą zrąb wykładu o ochronie przyrody na począt$\mathrm{ku}$ XX wieku.

M. Raciborski był autorem pierwszej w literaturze polskiej pracy naukowej o ochronie przyrody, ogłoszonej pod tytułem: Zabytki przyrody. ${ }^{8} \mathrm{~W}$ dziele tym Racioborski podkreślał znaczenie ochrony przyrody $\mathrm{w}$ badaniach naukowych, zwłaszcza "zabytków przyrody”, które charakteryzuja się rzadkością występowania i są śladem dawnych epok geologicznych. Do takich obiektów zaliczał skały, wodospady, jeziora, wyjątkowe zwierzęta, olbrzymie lub nieczęsto spotykane drzewa, osobliwe skupiska roślin. Postulował objąć ochroną gatunki będące reliktami minionych epok: przedlodowcowej i lodowcowej.

M. Raciborski rozpoczął pracę nad inwentaryzacją zabytków przyrody w Polsce, których owocem była książka: Ochrony godne drzewa i zbiorowiska rośli. ${ }^{9}$ Będąc członkiem Polskiego Towarzystwa Przyrodników im.

1896-1900 prowadził prace badawcze na Jawie, w 1900 roku objął Katedrę Botaniki w Akademii Rolniczej w Dublanach. w 1909 roku został profesorem Uniwersytetu im. Jana Kazimierza we Lwowie, gdzie zorganizowal Instytut Biologiczno-Botaniczny, a w 1912 roku - Uniwarsytetu Jagiellońskiego w Krakowie, gdzie z jego inicjatywy powstały Instytut Botaniczny i Ogród Botaniczny. Dorobek naukowy Raciborskiego obejmuje 183 prace z zakresu morfologii, anatomii i cytologii roślin, biologii ogólnej, fizjologii roślin, systematyki i florystyki, fitogeografii i paleobotaniki. Ponadto był on autorem pierwszej mapy geobotanicznej Polski, pionierem ruchu ochrony przyrody w Polsce i promotorem wydania wielotomowego dzieła zbiorowego Flora Polska (od 1908 roku). Spośród jego prac należałoby wymienić: Zabytki Przyrdy, Lwów 1908; ochrony godne drzewa i zbiorowiska roślin, KA 35/1910, 34/352-366; [z I.Sawickim] Badanie i ochrona zabytków przyrody: Program pracy dla dziataczy kulturalnych, Kraków 1914; Życie pod rów'nikiem, Kraków 1924. (or. W.S7AFER, M. RACIBORSKI. Obraz życia, tw'órczości naukow'ej i pracy spotecznej. Warszawa 1948; tenże, Dzieje oc/rony przyrody, 16-17; EP t. 3, 763; A. ZAWADZKA. Polscy botanicy w' stużbie ochrony przyrody, Warszawa 1986 (praca magisterska napisana pod kierunkiem prof. H. Sandnera w Katedrze Ekologii Czlowieka i Bioetyki w ATK, mszp w BIbliotece ATK). Lwów 1908.

$9 \quad$ KA 35/1910, 3-4-352-366. Warto też wspomnieć o jego pracy Wskazówki dla zakładających muzea przyrodniczo-krajoznawcze, Lwów 1911. 
Kopernika niestrudzenie też zabiegał o uświadomienie społeczeństwu konieczności ochrony przyrody i związanych z tym problemów.

2. Stanisław Sokołowski (1865-1942), Marian Sokołowski (1884-1939) i Bolesław Hryniewiecki (1875-1963) należą do grona polskich botaników, którzy kładli fundament pod polską naukę o ochronie przyrody.

S. Sokołowski ${ }^{10}$ był profesorem Uniwersytetu Jagiellońskiego, w latach 1905-1919 redaktorem pisma „Sylwan”, w którym uzasadniał konieczność ochrony lasów polskich, członkiem Państwowej Rady Ochrony Przyrody oraz organizatorem i założycielem narodowego Parku Tatrzańskiego.

M. Sokołowski ${ }^{11}$ ukończył studia botaniczne w Uniwersytecie Jagiellońskim, gdzie w 1924 roku uzyskał też stopień doktora filozofii. Badania naukowe prowadzil z zakresu botaniki, leśnictwa i ochrony przyrody. Pracował w Komisji Ochrony Przyrody, a po utworzeniu Państwowej Rady Ochrony Przyrody był jej członkiem i kierownikiem Biura w Krakowie. Należał do Ligi Ochrony Przyrody i Polskiego Towarzystwa Botanicznego. M. Sokołowski był orędownikiem idei utworzenia Tatrzańskiego Parku Natury (Narodowego) oraz rzecznikiem racjonalnej gospodarki rolnej. Problematykę ochrony przyrody opierał na czterech motywach:

- motyw przyrodniczy: prowadzenie badań naukowych związanych $\mathrm{z}$ ochroną przyrody;

- motyw estetyczny: dążenie do zachowania piękna krajobrazu;

- motyw historyczny: podkreślanie aspektu patriotycznego związanego z ochroną przyrody;

10 Stanisław Sokolowski (1865-1942) urodził się w Mloszowie, seminarium nauczycielskie ukończył w Krakowie, a studia w Wiedniu w 1893 roku. Po studiach pracowal w Krajowej Szkole Gospodarstwa Lasowego we Lwowie, a po jej przekształceniu w Wyższą Szkołę Lasową kontynuował w niej pracę jako profesor do 1919. W latach 1919-1935 byl profesorem Uniwersytetu Jagiellońskiego i kierownikiem Katedrz Laśnictwa w tym uniwersytecie. W 1930 roku został członkiem Polskiej Akademmii Umiejętności. Ponadto byl redaktorem pisma ,Sylwan”, założył ogród denrologiczny w Winnikach pod Lwowem oraz był niestrudzonym pinierem ochrony przyrody w Polsce. $Z$ prac jego należy wymienic: Hodowla ladu (1912, 1930); Budowa roślin drzewiastych (1927); Las tatrzański (1936); Tatry jako Park Narodowy (1923). (Por. P. SKAWIŃSKI, Stanistaw Sokotowski (1865-1942), w: Twórcy $i$ dziatacze ochorny przyrody w Polsce, Warszawa 1987).

11 Marian Sokołowski (1884-1939) urodział się w Wiedniu, szkołę średnią ukończył w Krakowie, a studia botaniczne w Uniwersytecie Jagiellońskim, gdzie uzyskal habilitację. Byl autorem prac z następujących dziedzin: fitosocjologii, biologii i hodowli lasu, fitogeografii i ochorny przyrody, zwłaszcze tatrzańskiej. Od 1924 roku był kierownikiem Zakładu Hodowli Lasu w Szkole Głównej Gospodarstwa Wiejskiego w Warszawie. Z jegoprac należaloby wymienić nastęujące: Chrońmy przyrodę ojczystą i jej zabytki, Kraków 1924; Ochrona przyrody w szkole. Wartość idei ochrony przyrody w wychowaniu i kształceniu młodzieży, Kraków 1927; Szkody od powału w lasach tatrzańskich i sposoby zapobiegania im w zakresie hodowli lasu, Kraków 1934; Szara roślinna Tatr Polskich, Zakopane 1935. (Por. M. ZAJĄCZKOWSKI, Życiorysy $i$ u'spomnienia, „Ziemia”/1939, 2/45-76; EP t. 4, 231.). 
- motyw wychowawczy: zwracanie uwagi na problematykę wychowawczą i dydaktyczną związana z ochroną przyrody.

B. Hryniewiecki ${ }^{12}$ studia rozpoczął w Uniwersytecie Warszawskim, a a kontynuował je w latach 1895-1900 w Uniwersytecie w Dorpacie. Po odzyskaniu niepodległości został powołany na profesora Uniwersytetu Warszawskiego i dyrektora Ogrodu Botanicznego. Na rzecz ochrony przyrody pracował jako przewodniczący Komisji Ochrony Przyrody, a później jako przewodniczący Państwowej Rady Ochrony Przyrody. Działał również w Lidze Ochrony Przyrody i w Towarzystwie Przyrodników im. Kopernika. Po drugiej wojnie światowej wrócił na stanowisko kierownika Katedry Systematyki i Geografii Roślin i na stanowisko dyrektora Ogrodu Botanicznego w Warszawie. B. Hryniewiecki był popularyzatorem idei ochrony przyrody, zwłaszcza lasów polskich, oraz orędownikiem ochrony lasów podmiejskich przy wielkich miastach polskich.

3. Jan Gwalbert Pawlikowski ${ }^{13}$ (1860-1939) w latach 1891-1904 byl profesorem Akademii Rolniczej w Dublanach, a od 1925 roku członkiem Polskiej Akademii Umiejętności. Główną jego troską była ochrona przyrody, zwłaszcza ochrona Tatr. W 1912 roku był współzałożycielem Sekcji Ochrony Tatr, która powstała w ramach Towarzystwa Tatrzańskiego i

12 Bolesław Hryniewicki (1875-1963) urodził się w Międzyrzeczu Podlaskim, w 1893 roku ukończył gimnazjum i rozpoczął studia na Uniwersytecie Warszawskim, ale za działalność społeczno-polityczną został wydalony z uczelni i zesłany w gląb Rosji. W 1895 roku został zwolniony na podstawie amnestii. Z braku możliwości powrotu do kraju, kontynuowal studia w Uniwersytecie w Dorpacie, gdzie je ukończył jako botanik i chemik ze stopniem kandydata nauk przyrodniczych, w 1900 roku został asystentem przy Katedrze Botaniki, a w 1904 roku - docentem prywatnym. Następnie odbywa podróże naukowe do Jeny, do Lipska i do Grazu. W 1910 roku zostaje profesorem na Wyższych Kursach Przyrodniczo-Medycznych w Dorpacie, a w 1914 roku otrzymuje stopień doktora botaniki (najwyższy stopień naukowy w Rosji carskiej) i zostaje profesorem zwyczajnym w Katedrze Morfologii i Systematyki Rośtin oraz dyrektorem Ogrodu Botanicznego w Odessie. Po pierwszej wojnie światowej w 1919 roku zostaje powołany na stanowisko profesora systematyki i geografii roślin w Uniwersytecie Warszawskim i na dyrektora Ogrodu Botanicznego w Warszawie. $\mathrm{Z}$ jego prac należaloby wymienić następujące: Nasze Lasy, Warszawa 1906; Zarys flory Litwy (1933); Lasy okolic Warszawy. Ich znaczenie i ochrona, Warszawa 1935; Zarys dziejów botaniki, Warszawa 1949 (Por. J. MIKLASZEWSKI, Prof. dr Bolestaw' Hryniewicki w' 35 rocznicę dziatanośi naukow'o-badawczej, pedagogicznej i spotecznej, ASBP 11/1934/1-12; Z. RADWAŃSKA-PARYSKA, Prof. Bolestaw Hryniewiecki - czlowiek i uczony, WB 7/1963, 3-4/173184; EP t.2 2,237.).

13 Jan Gwalbert Pawlikowski (1860-1939) był profesorem w Akademii Rolniczej w Dublanach w latach 1891-1904, a od 1925 roku - członkiem Polskiej Akademii Umiejętności. Poza problematyką związaną z ochroną Srodowiska zajmowat się zagadnieniami filozoficznymi i historiofilozoficznymi, zwlaszcza koncepcja J.Slowackeigo (por. SZAFER, Dzieje ochorny przyrody, 17-18; EP t.3, 475). 
miała na celu przede wszystkim zabezpieczać Tatry przed wszystkim, co mogłoby zniszczyć pierwotny charakter ich krajobrazu (budowle, urządzenia komunikacyjne, przemysł), oraz objąć ochroną górskie gatunki roślin i zwierząt, a także przeciwdziałać zaśmiecaniu gór. W 1913 roku ogłosił rozprawę: Kultura i natura, w której poddał analizie podstawowe pojęcia sozologiczne i określił cele ochrony przyrody. W 1923 roku założył nowe pismo „Wierchy", poświęcone głównie problematyce ochrony przyrody.

4. Bohdan Dyakowski ${ }^{14}$ (1864-1940) swoimi pracami naukowymi i popularnonaukowymi przyczyniał się do rozpowszechnienia idei ochrony przyrody. Do takich prac należałoby przede wszystkim zaliczyć: Nasz las i jego mieszkańcy (1898); Z naszej przyrody (1909); Historia naturalna, cz. 1 i 2 (1909); Nauka o rzeczach i przyrodzie (1918). Wprowadził swoistą metodykę i program nauczania o przyrodzie, w którym kładł nacisk na ekologiczny punkt widzenia oraz podejście populacyjne w wykładzie biologii. Pracował jako pedagog i był współzałożycielem Ligi Ochrony Przyrody.

5. Michał Siedlecki ${ }^{15}$ (1873-1940) od 1919 roku zajmował się stroną organizacyjną ochrony przyrody w Polsce. Między innymi prowadził badania w zakresie biologii mórz, których celem było stworzenie racjonalnych podstaw rybołówstwa morskiego. W 1923 roku został członkiem Państwowej Rady Ochrony Przyrody. Był również delegatem Polski w Międzynarodowym Biurze Ochrony Przyrody w Brukseli i stałym delegatem Polski w Międzynarodowej Radzie Badań Morza w Kopenhadze. Swoimi pracami naukowymi położył wielkie zasługi w ochronie wielorybów, jesiotra, ryb łososiowatych, żubra i ptaków.

14 Bohdan Dyakowski (1864-1940), biolog, pedagog, popularyzator nauk przyrodniczych w zakresie ochrony przyrody, działal w Krakowie od 1905 roku. Autor ponad 50 książek i podręczników szkolnych (por. SZAFER, Dzieje ochorny przyrody, 18; EP t. 1, 641).

15 Michal Siedlecki (1873-1940), zoolog, od 1903 roku czlonek Polskiej Akademii Umiejętności, w latach 1920-1918 profesor zoologii Uniwersytetu Jagiellońskiego, w latach 1919-1922 profesor i rektor Uniwersytetu Stefana Batorego w Wilnie, a od 1923 roku ponownie profesor zoologii w Krakowie. Tak jak wielu innych profesorów, 6 listopada 1939 roku zostal wywieziony z Krakowa przez hitlerowców do Sachsen-hausen, gdzie zmarł 11 stycznia 1940 roku. Poza pracami z zakresu ochrony środowiska prowadzil badania baukowe w zakresie cytologii i protozoologii. Pracowal w Instytucie Pasteura w Paryżu, w stacjach morskich (Neapol i Wimereux) oraz odbył podróże do krajów tropikalnych (Egipt, Jawa, Cejlon). (Por. „Wszechświat" /1955, 8-9/ [poświęcony M.Siedlckiemu]; C. DOBELL, Michat Siedlecki (1873-1940) a Founder of Modern Knowledge of the Sporozoa, P 33/1941; EP t. 4, 177.). 
6. Adam Wodziczko ${ }^{16}$ (1887-1948) zorganizował w Uniwersytecie Poznańskim im. Adama Mickiewicza międzywydziałowe seminarium Biocenotyki i Ochrony Przyrody oraz Zakład Ochrony Przyrody i Uprawy Krajobrazu. Jego staraniem również powstaty trzy parki narodowe: Wielkopolski, Woliński i Słowiński. A. Wodziczko doprowadził do powstania na Uniwersytecie im. Mikołaja Kopernika w Toruniu pierwszej Katedry Ochrony Przyrody. Stworzył teoretyczne podstawy badań naukowych $z$ zakresu ochrony przyrody. Jako pierwszy w Polsce podniósł zagadnienie ochrony krajobrazu ze względu na jego stepowienie. Był zwolennikiem dłogoplanowej gospodarki w krajobrazie opartej na przesłankach biologicznych. W wyniku swoich obserwacji naukowych zwrócił uwagę na proces stepowienia Wielkopolski. A. Wodziczko był członkiem Państwowej Rady Ochrony Przyrody na Wielkopolskę i Pomorze.

7. Władysław Szafer ${ }^{17}$ (1886-1970) podjął badania naukowe i organizacyjne $w$ zakresie ochrony przyrody. W latach 1919-1949 był przewodniczącym Państwowej Rady Ochrony Przyrody, w 1952 roku zorganizował Zakład Ochrony Przyrody Polskiej Akademii Nauk i Instytut Botaniki PAN w Krakowie i do 1961 roku był dyrektorem obu tych placówek. Pod jego redakcja zostały wydane następujące prace zbiorowe: Skarby przyrody i ich ochrona, Warszawa 1932; Ochrona przyrody i jej zasobów - problemy i metody, t. 1 i 2, Kraków 1965; Ochrona przyrodniczego środowiska człowieka, Warszawa 1973; oraz czasopisma związane z ochroną przyrody: "Ochrona Przyrody" i „Chrońmy Przyrodę Ojczystą".

16 Adam Wodziczko (1887-1948), botanik, członek Poznańskiego Towarzystwa Przyjaciół Nauk, od 1920 roku profesor anatomii i fízjologii roślin Akademii Rolniczej w Bydgoszczy, a od 1922 roku profesor Uniwersytetu Adama Mickiewicza w Poznaniu. Jest autorem ponad 200 rozpraw naukowych; oto niektóre z nich: Fizjotaktyka - nowa gałąź wiedzy o stosunku człowieka do przyrody, SPTPN 8/1934/117-118; Kierunki wspótczesnej ochrony przyrody, PiT 4/1935/145-148; Ochrona przyrody jako nauka i jej potrzeba, CPO 1/1945, 2-3/8-15; Ochrona przyrody umiejętnością praktyczna, wiedzą stosowaną i samodzielną nauką, SPTPN 13/1945-1946/106-110; Uwagi o nauczaniu ochorny przyrody w szkołach wyższych, CPO 2/1946, 3-4/28-35; Na straży przyrody, Warszawa 1967. (Por. SZAFER, Dzieje ochrony przyrody, 20-21; EP t. 4, 680.).

17 Władysław Szafer (1886-1948), botanik, od 1917 roku profesor Uniwersytetu Jagiellońskiego i dyrektor Ogrodu Botanicznego w Krakowie, od 1920 roku członek Polskiej akademii Umiejętności, a od 1952 roku czlonek Polskiej Akademii Nauk, w okresie okupacji hitlerowskiej organizator i rektor konspiracyjnego Uniwersytetu Jagiellońskiego. Z licznych jego prac należy wymienić następujące: Pamiątka pienicka, S 30/1912/1-6; Osobliwości i zabytki flory okolic Lwowa, RWMD 1/1914, 1-2/; Pierwsze karty z historii Białowieskiego Parku Narodowego, KA 6/1957/469-475; Kierunki rozwoju ochorny przyrody w Polsce, NP 6/1958, $2 /$ 14-60; Historia utworzenia na Babiej górze Parku Narodowego, w; Babiogórski Park Naorodwy, Kraków 1963; Dwanaście lat walki o utworzenie Pienińskiego Parku Narodowego, CPO 20/1964, 1/3-20; Zarys historii ochorny przyrody, w : Ochrona przyrody i jej zasobów - problemy i metody, pod red. W.Szafera, t. 1, Kraków 1965. (Por. SZAFER, Dzieje ochrony przyrody, 15-31; EP t. 4, 339.). 
8. Walery Goetel ${ }^{18}$ (1889-1972) wprowadził na określenie badań naukowych z zakresu ochrony przyrody nowy termin: sozologia, który powoli przyjmuje się w słownictwie krajowym i międzynarodowym. Spośód licznych zagadnień tej nauki szczególną uwagę zwracał na następujące tematy:

- ochrona wód, powietrza i gleb;

- ochrona gatunkowa roślin i zwierząt;

- ochrona krajobrazu i pielęgnowanie parków narodowych;

- ochrona życia i zdrowia człowieka.

W. Goetel wydał ponad sześćset prac naukowych i popularnonaukowych; część z nich opublikował w czasopiśmie "Wichry", którego był redaktorem i przewodniczącym Komitetu Redakcyjnego.

9. Julian Aleksandrowicz ${ }^{19}$ (1908-1988) wprowadził do zagadnień ekologicznych i ochrony przyrody bardzo ważny element $\mathrm{z}$ zakresu antroposfery, a mianowicie aspekt humanistyczny, dotyczący sumienia ludzkiego wrażliwego na wartości środowiska. Prace jego koncentrowały się wokół zdrowia człowieka i stały się podstawą do rozwoju filozofii medycyny i ekomedycyny.

10. Henryk Sandner (1915-1994) pracowal w Katedrze Zoologii w Uniwersytecie Łódzkim (945-1950), w Instytucie Zoologicznym PAN w Łodzi do 1954 roku, następnie w Instytucie Ekologii Polskiej Akademii Nauk, w Szkole Głównej Gospodarstwa Wiejskiego - Akademii Rolniczej, na Katolickim Uniwersytecie Lubelskim i w Akademii Teologii Katolickiej w Warszawie. W pracach naukowych Profesora przejawia się duża troska o ochronę przyrody, zwłaszcza w pracy w Katedrze Ochrony Środowiska na KUL-u i w sekcji Ekologii Człowieka i Bioetyki w ATK.

11. Włodzimierz Michajłow (1905-1994) w badaniach naukowych zarówno w SGGW jak i w zakładzie Parazytologii PAN w Warszawie pro-

18 Walery Goetel (1889-1972), geolog, od 1919 roku profesor Akademii Górniczo-Hutniczej w Krakowie i jej długoletni rektor, a od 1952 roku czlonek Polskiej Akademii Nauk. Z wielu jego prac należy wymienić następujące: O trawałości użytkowania zasobów przyrody, NP 3/ 1963-11-50; Gospodarcze motyn'y ochorny przyrody i jej zasobów', w: Ochrona przyrody $i$ jej zasobów: Problemy i metody, red. W. Szafer, t. 1, Kraków 1965; Sozologia - nauka o ochronie przyrody i jej zasobów, KA 15/1966/473-482; Sozologia, nauka o ochronie przyrody i jej zasobów, KA 21/1972/31-38. (Por. SZAFER, Dzieje ochrony przyrody, 23-24; M. RAJCA, Walery Goetel jako sozolog. Praca magisterska napisana pod kierownictwem prof. dra hab. Henryka Sandnera, ATK, Warszawa 1987, mszp w Bibliotece ATK.).

19 Julian Aleksandrowicz (1908-1988) - do głównych jego prac z zakresu ekologii należy zaliczyć następujące: Wiedza stwarza nadzieję (1976); Sumienie ekologiczne, Warszawa 1979; U progu medycyny jutra (1988 z H. Dudą); z P. WASZCZENKO, Środow'isko w' perspektyw'ie medycznej, w: CŚZ, 83-92. 
wadził badania w zakresie ochrony środowiska w latach 70. XX wieku i w swoich pracach w tytułach używał terminu sozologia na oznaczenie nauki o ochronie środowiska, podając syntetyczne definicje tej nauki.

Badania naukowe, działania organizacyjne i wydawnicze wymienionej grupy uczonych polskich stworzyły sprzyjające warunki powstania i rozwoju sozologii w Polsce. Prace ich, nacechowane miłością do ziemi ojczystej i troską o dobro wspólne, jakim jest przyroda ojczysta, kształtowały świadomość ekologiczną i nawoływały do odpowiedzialności za działalność gospodarczą i społeczną człowieka.

W Akademii Teologii Katolickiej a obecnie w Uniwersytecie Kardynała Stefana Wyszyńskiego na Wydziale Filozofii Chrześcijańskiej w Specjalności Ekologii Człowieka i Bioetyki prowadzone są badania naukowo-dydaktyczne w czterech katedrach: Filozofii Człowieka, Filozofii Ekologii, Historii i Filozofii Nauki, Bioetyki. Zespół - od ponad 15 lat pracował $w$ tej specjalności pod kierunkiem ks. prof. dr hab. Bernarda Hałaczka a obecnie pracuje pod kierunkiem J. M. Dołęgi. Prowadzone badania naukowe w poszczególnych katedrach maja charakter historyczny, rejestracyjno-sprawozdawczy, syntetyczny i prognostyczny. Obecnie prowadzone są starania o zorganizowanie badań w Katedrze Ekologii Człowieka i w Katedrze Podstaw Ochrony Środowiska. Od 1999 roku w ramach Uniwersytetu Kardynała Stefana Wyszyńskiego obok tej sekcji funkcjonuje Centrum Ekologii Człowieka i Bioetyki UKSW, które prowadzi podyplomowe studia w zakresie bioetyki, profilaktyki uzależnień i ekologii człowieka - edukacja ekologiczna.

\section{3. Od raportu U. Thanta do konferencji w Rio de Janerio i do Johanesburga 2002 Rio+10}

Do międzynarodowych uwarunkowań powstania sozologii zaliczamy przede wszystkim działania organizacji międzynarodowych, które w swoich programach uwzględniały problematykę związaną z ekologią człowieka i podejmowały wysiłki mające na celu ochronę środowiska naturalnego ${ }^{20}$.

20 Przykładowo wymieńmy nastęujące organizacje międzynarodowe: Organizacja Narodów Zjednoczonych; Organizacja Narodów Zjednoczonych do Spraw Oświaty, Nauki i Kultury; Międzynarodowy Fundusz Narodów Zjednoczonych Pomocy dzieciom; Światowa Organizacja Zdrowia; Organizacja do Spraw Wyżywienia i Rolnictwa. 
Wyrazem takich działań był raport U.Thanta ${ }^{21}$ z 26 maja 1969 roku, w którym wymienia się następujące zagadnienia, wymagające pilnej dyskusji na forum międzynarodowym:

- osiedla ludzkie a rozwój przemysłowy,

- racjonalne wykorzystanie i rozwój zasobów naturalnych naszej planety;

- zatruwanie i zanieczyszczanie środowiska życia człowieka;

- ochrona wartości środowiska ludzkiego.

Raport powyższy stał się podstawą powołania specjalnej Komisji Narodów Zjednoczonych, która przygotowała konferencję międzynarodową w Sztokholmie w 1972 roku.

Przez UNESCO został przyjęty w 1970 roku program MaB (Man and Biosphere), za którego realizacje w Polsce jest odpowiedzialne Prezydium Komitetu "Człowiek i Środowisko", działające przy Prezydium Polskiej Akademii Nauk. W tymże programie bierze udział około 50 państw, a nad realizacja programu czuwa Rada Koordynacyjna, w skład której wchodzi 25 państw wraz z Polską. Międzynarodowa i interdyscyplinarna realizacja tego programu została podjęta w 1972 roku. Dotąd zostały zapoczątkowane badania nad następującymi projektami tego programu ${ }^{22}$ :

- Ekologiczne skutki działalności ludzkiej w ekosystemach puszcz tropikalnych i subtropikalnych;

- Skutki ekologiczne metod eksploatacji oraz sposobów użytkowania gleby; wpływ na krajobraz lasów w strefie umiarkowanej i śródziemnomorskiej;

- Wpływ działalności człowieka i metod użytkowania ziemi na pastwiska od stref umiarkowanych do suchych (sawanny, tundry);

- Ekologiczne skutki działalności człowieka w strefach miejskich, przemysłowych i wiejskich, zwlaszcza docenienie znaczenia jezior, bagien, wód bieżących jako rezerw produkcji zwierzęcej, zachowania fauny i flory oraz miejsc rozrywki i wypoczynku;

- Skutki działalności ludzkiej w ekosystemach górskich;

- Energia i racjonalne wykorzystanie ekosystemów wysp;

- Zachowanie stref naturalnych oraz znajdujących się w nich zasobów genetycznych;

21 U. THANT, Czlowiek i jego środowiska, w: Dajcie szanse ziemi, wyboru dokonal J.Zieliński. Warszawa 1971, 233-282. U Thant (1909-1974), polityk birmański, w latach 1957-1961 stały przedstawiciel Birmy w ONZ, a w latach 1962-1971 pełniący funkcję Sekretarza Generalnego w tej organizacji, zasłynął jako rzecznik polityki pokojowego współistnienia, inicjator międzynarodowych przedsięwzięć zmierzających do ochrony środowiska, rozjemca w wielu sporach międzynarodowych, zwłaszcza w czasie kryzysu w strefie Morza Karaibskiego oraz w okresie narzmiałych konflikótw USA - Wietnam i Izrael - kraje arabskie. Na uwage zasługuja jego prace: Democracy in Schoool (1952), History of Post-War Burma (t. 1 i 2, 1961 ). Zadania nauki w dziedzinie racjonalengo kształtowania środowiska człowieka, red, wydania J. Stępień, Wrocław 1974, 14-15. 
- Ekologiczna ocena walki ze szkodnikami oraz wpływ użycia nawozów mineralnych na ekosystemy wodne i lądowe;

- Wpływ budowy niektórych obiektów na życie i zdrowie człowieka oraz na jego środowisko;

- Ekologiczne aspekty użytkowania energii w zespołach miejskich i przemysłowych;

- Skutki przekształceń demograficznych dla środowiska;

- Postrzeganie jakości środowiska;

- Zanieczyszczenie biosfery;

- Zmiany klimatu kuli ziemskiej pod wpływem działalności człowieka. Polskie komisje Komitetu „Człowiek i Środowisko” biorą udział w pracach 10 projektów programu ${ }^{23}$.

Międzynarodowa Rada Unii Naukowych (ISCU), powstała w 1971 roku, i Komitet Specjalny tej Rady (SCOPE) polecił różnym organizacjom naukowym opracować następujące problemy:

- wzrost gęstości zaludnienia na kuli ziemskiej;

- wzrost zawartości dwutlenku węgla w atmosferze;

- wzrost innego typu zanieczyszczeń atmosfery;

- wzrost zanieczyszczeń oceanów i wód śródlądowych;

- wzrost zanieczyszczen $w$ wodach naturalnych, atmosferze, glebie i żywych organizmach;

- nieodwracalne zmiany $w$ atmosferze wywołane działalnością człowie$\mathrm{ka}$;

- skutki introdukcji nowych gatunków;

- zasoby wodne;

- eutrofizacja wód śródlądowych;

- erozja i destrukcja gleby;

- hałas jako zanieczyszczenie środowiska;

- rozsiewanie zanieczyszczeń w powietrzu, wodzie, glebie i wskutek tego skażenie żywych organizmów;

- degradacja naturalnych ekosystemów oraz związane z nią destrukcja i zagłada wyposażenia genowego organizmów;

- zagrożenia techniczne atmosfery i wód międzynarodowych.

Powyższa lista zagadnień i problemów uświadamia nam ogrom pracy i wskazuje na obszar wstępnych badań naukowych związanych $z$ ochrona środowiska.

W maju 1971 roku odbyło się w Pradze Sympozjum Europejskiej Komisji Gospodarczej Organizacji Narodów Zjednoczonych poświęcone kontynentalnym zagadnieniom ochrony środowiska europejskiego ${ }^{24}$.

23. MICHAJłOW, Sozologia i problemy, 16-17.

24 Tamże, s. 17-18, Por. także J. FILIPEK, Podstaw'y pran'ne ochrony przyrodniczego środowicka cztowieka w niektórych krajach poza Polska, w: Ochrona przyrodnczego środowiska czlowieka, 141-147. 
Rada Zarządzająca „Programu Środowiska” (UNEP) przy Organizacji Narodów Zjednoczonych w marcu 1974 roku w Nairobi (Kenia) podjęła próbę klasyfikacji zagrożeń naturalnego środowiska współczesnego człowieka ${ }^{25}$. Na konferencji tej wyznaczono kierunki działań na najbliższe lata, zwracając uwagę na następujące zagadnienia i problemy:

- osiedla ludzkie;

- zdrowie i dobre samopoczucie człowieka;

- środowiska glebowe i wodne zwłaszcza w strefach pustynnych i ze szczególnym uwzględnieniem procesów pustynnienia;

- handel, ekonomia, technologia, upowszechnianie techniki a środowisko;

- zanieczyszczenie oceanów i ich zasobów;

- ochrona przyrody w sferze zasobów genetycznych przyrody żywej;

- źródła energii oraz ich znaczenie dla środowiska.

Wymienione przykładowo działanie Organizacji Narodów Zjednoczonych wskazują na znaczenie i potrzebę podjęcia badań naukowych $\mathrm{w}$ zakresie ochrony naturalnego środowiska człowieka, prób opisania i klasyfikacji istniejących już zagrożeń i zanieczyszczeń tego środowiska oraz uzasadnienie racjonalnego gospodarowania naturalnymi zasobami środowiska człowieka, i to zasobami naturalnymi zarówno przyrody nieożywionej, jak i ożywionej. Wspomniane przedsięwzięcia Organizacji Narodów Zjednoczonych były też głównymi międzynarodowymi uwarunkowaniami powstania sozologii. Do powstania tej nauki przyczyniła się też działalność Międzynarodowej Unii Ochrony Przyrody i Jej Zasobów, z którą współpracuje Komitet Naukowy Ochrony Przyrody i Jej Zasobów istniejący przy Polskiej Akademii Nauk.

Znaczącym wydarzeniem na początku lat 90 . XX wieku bała konferencja ekologiczna Narodów Zjednoczonych w Rio de Janeiro od 3 do 14 czerwca 1992 roku pod tytułem „Środowisko i Rozwój”. Najważniejsze dokumenty $\mathrm{z}$ tej konferencji:

1. Deklaracja z Rio w sprawie środowiska i rozwoju;

2. Globalny program działań: Agenda 21;

3. Konwencja w sprawie zmian klimatu;

4. Konwencja o różnorodności biologicznej;

5. Konsensus w sprawie lasów (ochrona, rozwój, zarządzanie).

Ważne wydarzenia międzynarodowe $w$ tym czasie to oficjalne podsumowanie Agendy 21 w Rio 13-19 marca 1997 przez organizacje pozarządowe "Od Agendy do działania" z udziałem przedstawicieli 150 państw i w dniach 23-27 czerwca 1997 roku w Nowym Jorku odbyła się konferencja Narodów Zjednoczonych - „Szczyt Ziemi plus 5”. Analizę

MICHAJŁOW, Sozologia i problemy, 14-15; por. T. SZCZESSNY, Międzynarodow'e problemy ochrony przyrodniczego środowiska cztowieka, w: Ochrona przyrodnicznego środowiska cztowieka, 107-114. 
tych wydarzeń znajdujemy w pracy S. Kozłowskiego: Ekologiczne problemy przyszłości śzviata $i$ Polski.

Wydarzenia te $\mathrm{i}$ inne $\mathrm{z}$ zakresu problematyki ekologicznej wymuszaja podejście w sozologii - globalne, interdyscyplinarne i systemowe.

\section{4. W kierunku sozologii systemowej}

Międzynarodowa konferencja „Środowisko i Rozwój” z 1992 roku stała się faktem ożywiającym prace naukowo-badawcze i działania polityczno-praktyczne w dziedzinie ekologii i ochrony środowiska. Wymienimy tutaj główne wydarzenia międzynarodowe i krajowe, które mają duże znaczenie przede wszystkim poznawcze $w$ podjętym zadaniu charakterystyki sozologii systemowej.

1. Do wydarzeń międzynarodowych należy zaliczyć wspomniane re konferencje związane $z$ oceną realizacji Agendy 21 po pięciu latach, czyli Rio + 5: „Od Agendy do działania” (13-19 marzec 1997, Rio de Janeiro); "Szczyt Ziemi plus 5" (23-27 czerwiec 1997, Nowy Jork).

$Z$ konferencji pierwszej warto podkreślić konsultacje regionalne dotyczące wdrażania w życie zrównoważonego rozwoju w Europie Środkowo-Wschodniej. Spostrzeżenia te dotyczą następujących zagadnień:

- braku szerokiego udziału społecznego w tym programie;

- niedostateczne zainteresowanie mediów procesem zrównoważonego rozwoju;

- niedostateczne środki finansowe na ten cel;

- niezrównoważona konsumpcja;

- brak harmonizacji regionalnych norm i standardów ochrony środowiska;

- brak publicznej czujności na problemy ochrony środowiska;

- wzmacnianie i wprowadzanie systemu informacji $w$ tym zakresie.

$Z$ drugiej konferencji należy podkreślić uwagi dotyczące następujacych problemów:

- postępujący wzrost emisji dwutlenku węgla;

- wzrost zanieczyszczenia środowiska motoryzacją i transportem;

- postępująca degradacja i zagłada lasów, szczególnie tropikalnych;

- pogarszający się stan mórz i oceanów;

- obniżenie się różnorodności biologicznej planety, zanik niektórych gatunków;

- wzrastająca liczba ludzi niedożywionych i żyjących w nędzy;

- nasilanie się konsumpcyjnego stylu życia w krajach bogatych;

- niedostateczna społeczna świadomość ekologiczna narastających zagrożeń;

- nie zrealizowanie zobowiązań z Rio de Janerio. 
2. Z krajowych wydarzeń o zasięgu ogólnopolskim i międzynarodo- )wym należy podkreślić cały szereg konferencji naukowych o problematyce ekologicznej. Tutaj wymienimy dla przykładu tylko niektóre $\mathrm{z}$ nich z lat 90 . XX wieku.

- II Ogólnopolska Konferencjia Ochrony Środowiska w Nauczaniu i Wychowaniu, 7-9 czerwca 1993 w Politechnice Lubelskiejej.

- Człowiek i środowisko - dyscypliny humanistyczne i ekologia, seminarium zorganizowane $z$ okazji Centralnych Obchodów Światowego Dnia Ochronny Środowiska w Toruniu, 05 czerwca 199527;

- Na VI Zjeździe Filozoficznym w Toruniu Sekcja: ekofilozozofii i bioetyki $(1995)^{28}$;

- Agenda 21 - Realizacja zadań edukacyjnych, konferencja 5-7 maja 1997, Jedlnia-Letnnisko ${ }^{29}$;

- Ekologia - polityka - kultura. Społeczne przesłanki i przejawy kryzysu ekologicznego, konferencja naukowa w Przyjezierzu, 21-22 kwietnia $1998^{30}$;

- Kształcenie ekologiczne dorosłych, konferencja w Instytucie Badań Edukacyjnych w Warszawie, 16 czerwca $1998^{31}$;

- Etyka środowiskowa - teoretyczne i praktyczne implikacje, UMK, Toruń, 08 wrzesień $1998^{32}$;

- Podstawy edukacyjne kształcenia dla zrównoważonego rozwoju, konferencja w Centrum Edukacji Nauczycieli, Gdańsk, 25-27 maja 199933;

- Ekologia a transformacje cywilizacyjne na przełomie wieków, międzynarodowa konferencja na KUL-u, Lublin 16-17 września 19994;

- "Mnożnik cztery" szansą ekonomicznego rozwoju dla Polski, konferencja na Katolickim Uniwersytecie Lubelskim, Lublin, 6 kwietnia $2000^{35}$;

26 Por. Materiaty II Ogólnopolskie Konferencji Ochrony Środowiska w' nauczniu i wychow'aniu, pod red. M.R. Dudzińskiej i L. Pawłowskiego, PL, Lublin 1993.

27 Por. Cztowiek i środowisko - dyscypliny humanistyczne i ekologia, pod red. W. Tyburskiego, UMK i PKE OP-K, Toruń 1995.

28 Por. Ekofilozofia i bioetyka VI Polski Zjazd Filozoficzny, pod red. W. Tyburskiego, TOP Kurier, Toruń 1996.

29 Por. Edukacja środowiskowa, pod red. Danuty Cichy, IBE, Warszawa 1997.

3) Por. Polityka-Ekologia-Kultura. Spoteczne przestanki i przejaw'y kryzysu ekologicznego, pod red. A. Papuzińskiego, WSP, Bydgoszcz 2000.

31 Por. Ksztalcenie ekologiczne dorostych, pod red. Danuty Cichy, PAN CiŚ ZN 23, IBE, Warszawa 1998.

32 Por. Etyka Srodowiskow'a - Teoretyczne i praktyczne implikacje, pod red. W. Tyburskiego, TOP Kurier, Toruń 1998.

33 Por. Podstawy Ksztatcenia dla zrównoważonego rozwoju, pod red. Danuty Cichy, PAN CiŚ, ZN 24, Warszwa 2000.

34 Por. Ekologia a transformacje cyn'ilizacyjne na przetomie n'ieków, pod red. S. Zięby i Z. Wróblewskiego, ZEC KUL, Lublin 2000.

35 Por. Wokót mnożnika cztery, pod red. S. Kozłowskiego i Z. Wróblewskiego, ZEC KUL, Lublin 2000; oraz sprawozdanie z dyskusji w CiP Nr 11-12 (2000). 
W dniach 30-31 maja 2000 odbyla się w Augustowie konferencja naukowa poświęcona Ekologii rodziny ludzkiej zorganizowana przez sekcję Ekologii Człowieka i Bioetyki WFCh UKSW, Instytut Studiów nad Rodziną UKSW, Sekcję Teologii Duchowaści i Katedrę Ekoteologii i Bioetyki WT UKSW, Wydział Pedagogiczny WM, WSD Łomża, WSD Ełk, Biuro poselskie Krzysztofa Anuszkiewicza w Augustowie.

15 lat Ekologii człowieka i bioetyki na Wydziale Filozofii Chrześcijańskiej ATK - konferencja naukowa (23-10-2000)poświęcona działalności sekcji: Ekologii Człowieka i Bioetyki oraz dyskusji na temat profilu humanistycznego ochronny środowiska.

Problematyka ekofilozoficzna wraz z filozofią przyrody i bioetyczna z etyką była szeroko reprezentowana przez wielu uczestników na VII Polskim Zjeździe Filozoficznym w dniach 12-18 września 2004 w Uniwersytecie Szczecińskim.

\section{5. Perspektywy rozwoju sozologii systemowej}

Perspektywy rozwoju sozologii zależą od określonych i realizowanych badań z zakresu naturalnego środowiska człowieka w skali międzynarodowej i krajowej. Międzynarodowe prace sozologiczne opierają się na dyspozycjach i programach działania organizacji międzynarodowych, np. ONZ, FAO, UNESCO. Natomiast badania naukowe z zakresu sozologii w Polsce zostały określone w uchwałach II Kongresu Nauki Polskiej, na którym na jednej płaszczyźnie stawiano zagadnienie produkcji i ochrony środowiska.

Każda nowa nauka domaga się rozstrzygnięcia wielu kwestii epistemologicznych i metodologicznych. Zadania te wyznaczaja jeden z kierunków badań prowadzonych w ramach sozologii. Opracowanie zagadnień epistemologicznych i metodologicznych sozologii warunkuje jej autonomiczność i jednoznaczne rozwiązywanie problemów merytorycznych $z$ zakresu ochrony społeczno-przyrodniczego środowiska człowieka.

Rozwiązanie wielu problemów sozologicznych jest jednak uzależnione od wyników badań $z$ innych dziedzin wiedzy. Wskazuje to na interdyscyplinarność sozologii i jej wielorakie związki z naukami medycznymi, biologicznymi, geologicznymi, technicznymi, ekonomicznymi, praw-

36 Por. Zadania nauki w' dziedzinie racjonalengo ksztaltowania środowiska człowieka, 40-88; J.J. NOWAK, Prawodaw'stwo ochrony przyrody i środowiska źyciow'ego czlowieka w' Polsce, w: Ochorna przyrodniczego środowiska cztowieka, 123-140; B. HALACZEK I M. LUBAŃSKI, Filozoficzne aspekty ekologii. CaW 5/1988.11-17; F. ROSIŃSKi, Odpowiedzialnośc moralna za ochronę środowiska, CaW 5/1988/18-27; A.L. SZAFRAŃSKI, Ochrona srodowiska w'świetle teologii, CaW 5/1988/4-10; J.J. SKOCZYLAS, Cywilnoprawne środki ochrony środowiska, Warszawa 1986. 
nymi, społecznymi, humanistycznymi, filozoficznymi i teologicznymi ${ }^{36}$. Osiągnięcia w tych naukach determinują pytania i odpowiedzi sozologii.

Kierunki rozwoju sozologii mogą oscylować wokół następujących zagadnień ${ }^{37}$ :

- rejestrowanie zakłóceń stanów równowagi między antroposferą a biosfera;

- przywracanie stanów równowagi między antroposferą a biosferą;

- kontrolowanie urządzeń technicznych i procesów technologicznych, mające na celu zabezpieczenie tzw. wyjść z zakładów przemysłowych zagrażających środowisku biologicznemu (zagadnienia protekcyjne);

- wprowadzanie nowych technologii wytwarzania, nieuciążliwych dla środowiska naturalnego (zagadnienia perspektywiczne).

W sozologii pojawiają się również problemy ekologiczne oraz zagadnienia $z$ nauk humanistycznych, np.: kształtowanie tzw. sumienia ekologicznego, opracowanie etyki ekologicznej, wywieranie nacisku na władze ustawodawcze i wykonawcze celem systemowego i całościowego rozwiązywania kwestii ochrony środowiska. Należy też mieć na uwadze związane $z$ ochroną środowiska programy wychowawcze i dydaktyczne realizowane $w$ szkolach podstawowych, średnich i wyższych.

Zasygnalizowane $w$ tym rozdziale uwarunkowania wyodrębnienia nowej nauki o ochronie przyrody, a zwłaszcza koncepcji sozologii systemowej wynikaja z już historycznych prac jej prekursorów, działalności ekologicznych organizacji międzynarodowych, dorobku uczonych polskich XIX i XX wieku zajmujących się ochroną przyrody i z perspektyw rozwoju tej nauki.

\section{Koncepcja sozologii systemowej}

\section{1. Wyjaśnienie terminów teoriopoznawczych}

W ludzkim poznaniu przednaukowym i naukowym występują zasadniczo następujące elementy strukturalne: pojęcia lub nazwy, sądy lub zdania, teorie i hipotezy oraz koncepcje.

Przez pojęcia ${ }^{38}$ rozumiemy w poznaniu przednaukowym najprostsze ujęcia poznawcze rzeczywistości nas otaczającej. Nie oznacza to, że pojęcia są naj-

37 Por. W. MICHAJŁOW, Sozologia - nauka o ochronie i ksztattow'aniu środowiska, w: Nowe specjalności w' nauce w'spótczesnej, pod red. T.Kotarbińskiego. W.Osińskiej, E.Geblewicza, Wrocław 1977, 162-163; A.Wodziczko, Kierunki współczesnej ochrony przyrody, PiT / $1935,4 / 145-148$.

38 Por. Maty stow'nik terminón' i pojęć filozoficznych, oprac. A.Podsiad, Z. Więckowski, Warszawa 1983, 175-276; M. A. KRĄPIEC, Język $i$ świat realny, Lublin 1985, 53-92. 
łatwiejszym sposobem poznania. Teoria poznania wyznacza szereg szczegółowych zagadnien, np. geneza pojęć, treść pojęć, zakres pojęć, znaczenie poznania zmysłowego i intelektualnego $w$ genezie i strukturze pojęcia. Badania metanaukowe koncentrują się na określeniu treści i zakresu podstawowych pojęć $\mathrm{w}$ poszczególnych dziedzinach poznania naukowego. W ujęciu logiczno-metodologicznym stosuje się inną terminologię, która za pomocą "nazw"39 ich treści i zakresu ujmuje ten sam lub podobny proces poznawczy człowieka. Wypracowanie pojęć w strukturze poznania naukowego wymaga nie raz bardzo długich i skomplikowanych zabiegów poznawczych, niemniej pojęcia stanowią podstawową strukturę poznawczą w każdej nauce.

W sądach ${ }^{40}$ lub zdaniach ${ }^{41}$ wyrażamy nasze poznanie dotyczące otaczającego nas świata, ludzi i nas samych. Te formy poznania funkcjonują zarówno w poznaniu przednaukowym, jak i naukowym.

Teorie $^{42}$ są bogatym, zarówno $w$ aspekcie treści, jak i formy, tworem poznania naukowego. Teoria naukowa ma strukturę logiczno-metodologiczną, jest uzasadniona, sprawdzalna i komunikatywna. W procesie tworzenia teorii naukowych występuje zazwyczaj etap formułowania hipotez naukowych, ${ }^{43}$ które po sprostaniu wymogom logiczno-metodologicznym mogą przejść $\mathrm{w}$ tezy naukowe.

Przez koncepcje ${ }^{44}$ rozumiemy ogólne założenia o charakterze teoriopoznawczym, ontologicznym i aksjologicznym. Założenia te ukierunkowują nasze spojrzenie poznawcze na dany przedmiot badań naukowych oraz pozwalają zaakcentować w strukturze poszczególnych dziedzin poznania te elementy, które są charakterystyczne dla danej nauki.

39 Por. L. GUMAŃSKI, Wprowadzenie w logikę w'spótczesnq, Toruń 1983, 24-26, 94.

40 Por. M. A. KRĄPIEC, Język i świat realmy, 93-138; M.GOGACZ, Ważniejsze zagadnienia metafizyki, Lublin 1973, 45-47; K. AJDUKIEWICZ, Logika pragmatyczna, Warszawa 1965; 27-29; M. A. KRĄPIEC, Język naturalny podmiotowo-orzeczeniow'y (analiza sqadów), w: Św. Tomasz, De ente et essentia. Przektad-komentarz-studia, M.A.Krąpiec, Lublin 1981, 140-162; A.B.STĘPIEŃ, Istnieie (czegoś) a pojęcie $i$ sqd, SPhCh 9/1973, 1/235-261; A.MARYNIARCZYK, Metoda separacji a metafizyka, Lublin 1985, 116-122.

41 Por. AJDUKIEWICZ, Logika pragmatyczna, 27-39; S.KAMIŃSKI, Elementy logiki formalnej, w: A.B.STEPIEŃ, Wstęp do filozofii, Lublin 19892, 269-277.

42 Por. C.G. HEMPEL, Podstawy nauk przyrodniczych, tłum. B.Stanosz, Warszawa 1968, 105112; E. NAGEL, Struktura nauki. Zagadnienia logiki wyjaśnień naukowych, thum. J.Giedymin, B.Pasalski, H.Eilstein, Warszawa 1970, 88-94; J. SUCH, Czy istnieje Esperimentum crucis? Problemy sprawdzania praw' i teorii naukowych. Studium metodologiczne, Warszawa 1975, 135-230; L. KUC, Z badań nad pjęciem ,teoria” w' szkole tomistycznej XV wieku, w: Studia z dziejow myśli swiętego Tomasza z Akwinu, pod red. S. Swieżawskiego i J.Czerkawskiego, Lublin 1978, 47-90.

43 Por. J. GIEDYMIN, Problemy zatożenia rozstrzygnięcia. Studia nad logicznymi podstaw'ami nauk spotecznych, Poznań 1964, 21, 67-73, 173; K. PASENKIEWICZ, Logika ogólna, Warszawa 1979, 17-20.

44 Por. E. MORAWIEC, Pozycja pierwszych zasad w koncepcji metafizyki J. Maritaina, SPhCh 9/1973, 1/179-205; K.KŁÓSAK, Koncepcja buty a filozofia Boga, SFB t. 3, 1977, 11-26; M. JAWORSKI, Problem koncepcji filozofii, AC 14/1982/1-9. 


\section{2. Empiryczna koncepcja sozologii}

Empiryczna koncepcja sozologii wchodzi w zakres jednej z współczesnych koncepcji nauki, jaką jest empiriologiczna teoria nauki. Współczesne teorie nauki, dotyczące nauk szczegółowych zarówno o przyrodzie, jak i o człowieku, pozostają w zgodzie $z$ zasadami współczesnego tomi$\mathrm{zmu}, \mathrm{w}$ ramach którego wyróżniamy następujące ich typy:

- empiriologiczną teorię nauki, ${ }^{45}$

- ontologizującą teorie nauki; ${ }^{46}$

- systemową teorię nauki. ${ }^{47}$

Interesuje nas $w$ tym miejscu empiriologiczna teoria nauki $i$, odpowiednio, empiriologiczna koncepcja sozologii.

Według empiriologicznej teorii nauki przedmiotem badań szczegółowych nauk o przyrodzie jest sfera zjawisk, inaczej mówiąc - aspekt zjawiskowy rzeczywistości, a celem ustalenie stałych relacji zachodzcaych między zjawiskami oraz sformułowanie praw rządzących tymi zjawiska$\mathrm{mi}^{48}$. Zwolennicy tej teorii wywodzący się $\mathrm{z}$ nurtu tomistycznego ${ }^{49}$ i autorzy spoza nurtu filozofii tomistycznej ${ }^{50}$ przyjmują, że przedmiotem badań $\mathrm{w}$ naukach przyrodniczych jest aspekt zjawiskowy rzeczywistości i zarazem kładą nacisk bądź na ujęcia realistyczno-eksperymentalne, bądź fenomenistyczno-eksperymentalne, bądź syntetyczne, łączące oba te stanowiska ${ }^{51}$. Uwzględniają też afilozoficzna tendencję, obecną $w$ badaniach przyrodniczych w czasach nowożytnych i współczesnych. ${ }^{52}$

45 Por. K. KŁóSAK, Z teorii metodologii filozofii przyrody, Poznań 1980, 13-41; R. Masi, H. NICOLETTIE, Cosmologia, Romae 1961, 134-236.

46 Por. K. KLÓSAK, $Z$ teorii metodologii filozofi przyrody, 22-28; J.M. DOLĘGA, Implikacje filozoficzne empiriologicznej fenomenologii ruchu, ZZFPIFP 7/1985/167-168.

47 Por. J M. DOŁEGGA, Stosunek ruchu do materii w' ujeciu klasycznej filozofii przyrody, Warszawa 1986, 15-17; A. NOWACZYK, Logiczne podstawy nauk ścistych, Warszawa 1985, 87187; A.TARGOWSKI, Informatyka. Modele systemów i rozwoju, Warszawa 1980, 260-415.

48 Por. K.KŁÓSAK, „Przyrodnicza” definicja duszy ludzkiej, jej uprawnienia i granice użyteczności naukow'ej, SPhCh 2/1966, 1/192-195; tenże, Z teorii i metodologii filozofii przyrody, 14. Odmienne stanowiska: M.GOGACZ, Cztowiek i jego relacje. Materiaty filozofii czton'ieka, Warszawa 1985, 76-78.

49 Zdaniem K. Kłósaka do zwolenników tej teorii należą następujący autorzy: J. Maritain, F. Reinoirte, F.X. Maquart, A. Brunner, F. van Steenberghen, F. Amerio, J. Hellen, R. Jolivet, I. Bonetti, J.P. Klubertans, J. de Tonqedec, E. Simard, R. Masii, H. Nicolettie (por. Z teorii i metodologii filozofii przyrody, 14).

5) Do zwolenników tej teorii, z poza nurtu filozofii tomistycznej, należą następujący autorzy: A. Einstein, L. de Broglie, A. Arzelies, C.G. Hempel, E. Nagel, T. Pawłowski, M. Przełęcki, J. Such (por. KLÓSAK, $Z$ teorii $i$ metodologii filozofii przyrody, 24-25).

51 Por. KŁÓSAK, Z teorii i metodologii filozofii przyrody, 14.

52 Por. K. KŁÓSAK, Zagadnienie teologicznej interpretacji przyrody w'e wspótczesnej neoscholastyce, w: Pod natchnieniem Ducha Świętego. Wspótczesna mysl teologiczna, Poznań 1964, 38; tenże, Z teorii i metodologii filozofii przyrody, 29. 
Do podstawowych metod stosowanych w naukach przyrodniczych należy, według empiriologicznej teorii nauki, zaliczyć:

- obserwacje naukową bezpośrednią, ilościową i jakościową;

- obserwacje naukowa pośrednią, ilościowa i jakościową, i eksperyment biologiczny;

- opis;

- pomiar;

- statystykę.

Bliższa analiza tych metod została przeprowadzona $\mathrm{w}$ poprzednim rozdziale. Tutaj natomiast jeszcze raz podkreślmy, że poprawne stosowanie tych metod pozwala usytuować poznanie typowe dla tych nauk $w$ płaszczyźnie empiriologicznej.

$Z$ dużym prawdopodobieństwem możemy twierdzić, że przyjmowane i właściwie stosowane metody nauk przyrodniczych nie pozwalają wyjść poza sferę zjawiskową rzeczywistości. Konsekwentne zaś postępowanie zapewnia tym naukom jednolitość przedmiotu badań, metod oraz teorii. ${ }^{53}$

Empiriologiczna koncepcja sozologii sprowadza się do dwóch podstawowych założeń. Pierwsze dotyczy przedmiotu badań sozologii, drugie - metod stosowanych w tej nauce. Sozologiczne badania naukowe prowadzone przy tych założeniach są badaniem strony zjawiskowej rzeczywistości na styku wzajemnego oddziaływania na siebie biosfery i antroposfery. Badania te opierają się na obserwacji naukowej jako jednej $z$ podstawowych metod sozologii.

Jeżeli opowiemy się za taką koncepcja sozologii, to tego rodzaju badania pozwolą uzyskać dokładny opis zjawisk i relacji zachodzących między nimi w biosferze, a powstałych pod wpływem oddziaływania na nią antroposfery.

\section{2. Humanistyczna koncepcja sozologii}

Humanistyczna koncepcja sozologii w całym procesie ochrony naturalnego środowiska człowieka przywiązuje wielką wagę do antroposfery, i to zarówno na etapie badań rozpoznawczych, dotyczących oddziaływania zmienionego środowiska naturalnego na somatyczną, psychiczna i duchową stronę człowieka, jak i na etapie rozwiązywania zagadnień kształ-

53 Por. KŁÓSAK, Z teorii i metodologii filozofii przyrody, 20; T. CZEŻOWSKI, O zwiqzkı między naukami aksjomatycznymi a naukami empirycznymi, SP 18/1973/11-18; S. KAMIŃSKI, Stosunek między poznaniem empirycznym a nieempirycznym w' nauce, w: $Z$ zagadnień kultury chrześciajniskiej, Lublin 1973, 253-264; P. ZEILER, O metodach formalnej rekonstrukcji teorii empirycznych, SF/1983, 10/27-37; R.WÓJCICKI, Wykłady z metodologii nauk, Warszawa $1982,35-70,150-277$. 
towania sumienia wrażliwego na wartości ekologiczne i tworzenia prawa biorącego $\mathrm{w}$ obronę wartości, jakie przedstawia środowiska naturalne.

Humanistyczne uwarunkowania, przesłanki czy założenia badań sozologicznych mają swą podstawę w wartościach humanistycznych. Spośród owych humanistycznych założeń sozologicznych badań naukowych należałoby wymienić następujące:

- przyroda, kosmos, całe środowisko przyrodnicze, które nas otacza, uznaje się za dzieło Boga Stwórcy; ${ }^{54}$

- człowiek, który jest szczególnym dziełem Stwórcy, stanowi w tym środowisku przyrodniczym określone centrum, w którym zbiegają się różne linie rozwojowe wszechświata,;

- w przyrodzie i człowieku dostrzega się dobro i piękno - wartości, które decydują o rozwoju osobowości człowieka;,56

- życie i zdrowie człowieka uznaje się za wartości najwyższe, ${ }^{.57}$

- etyka, moralność i prawo ekologiczne stanowią istotne elementy edukacji ekologicznej. ${ }^{58}$

Wymienione założenia wytyczają humanistyczną koncepcję sozologii, w ramach której określa się przedmiot i metody badań tej nauki. W koncepcji tej preferuje się metody humanistyczne, a przedmiotem zainteresowań jest sam czlowiek $z$ jego warstwą biologiczna i humanistyczną.

Stwierdzenie, że człowiek jest ośrodkiem wszechświata i że w nim zbiegają się różne linie rozwojowe, jest, w pewnym sensie, oparte na zasadzie antropicznej. Nie podejmujemy tutaj dyskusji na temat tej zasady. Odsyłamy Czytelnika do już bogatej literatury poświęconej tej kwestii. ${ }^{59} \mathrm{Nie}-$ mniej pragniemy przypomnieć zasadę antropiczną w nie budzącym większych zastrzeżeń sformułowaniu B. Cartera: „Wszechświat musi posiadać takie własności, które umożliwiają rozwój życia w określonym stadium

54 Por. JAN PAWEE II, Pokój z Bogiem Stw'órcq - pokój z catym stw'orzeniem, Rzym 1990 (orędzie papieża Jana Pawła II na XXIII Światowy Dzień Pokoju).

55 Por. J. van GERWEN, La paix Dieu Createur, la paix avec toute la creation, PMV 13/1990/ 38-44.

56 Por. E. TANG, La religion a-t-elle quelguq chose a voir avec l'ecologie? PMV, 13/1990/6/19.

57 Por. T. ŚLIPKO, Granice życia. Dylematy wspótczesnej bioetyki. Warszawa 1988; J.Blewett, La pensee sociale catholique en est-elle toujeurs a ses balbutiements, PMV 13/1990/28-37.

58 Por. ŚLIPKO, Granice życia, 22-47; S. KORNAS, Wspótczesne eksperymenty medyczne w ocenie etyki katolickiej, Częstochowa 1986; J. ALEKSANDROWICZ, Sumienie ekologiczne, Warszawa 1979; G. BIAŁKOWSKI, Uczony jako sumienie i duchon'y przewodnik spoteczenistwa, ZN 25/1989, 1/3-10.

59 J. ŻYCIŃSKI, Zasada antropiczna a teologiczne interpretacje przyrody, SPhCh 23/1987, $2 /$ 169-186; M. HELLER, Zasada antropiczna, w: M. HELLER, J. ŻYCIŃSKI, Dylematy ewolucji, Kraków 1990, 150-158; P.C.W. GAVIES, Zasada antropiczna, PF 37/1986/213259; J.LESLIE, Anthropic Princple, World Ensemble, Desing, APhQ 19/1982/141-151; M. ZABIEROWSKI, Zasada antropiczna w' fizyce n'spótczesnej, ZZFPiFP 10/1988/197-208. 
ewolucji kosmicznej" ${ }^{\prime 00}$. Natomiast radykalniejsze sformułowanie zasady antropicznej: „Życie, które powstało w procesie ewolucji kosmicznej, będzie zawsze istnieć we wszechświecie"61, budzi sporo wątpliwości.

Zakładając humanistyczną koncepcje sozologii i stosując metody humanistyczne można wyjść poza sferę zjawiskową właściwego przedmiotu jej badań i podjąć próbą ujęcie, w aspekcie filozoficznym, istoty człowieka.

\section{3. Filozoficzna koncepcja sozologii}

U podstaw filozoficznej koncepcji sozologii znajdują się założenia filozoficzne dotyczące człowieka, przyrody i aksjologii. Inaczej mówiąc, koncepcja ta opiera się na filozoficznej koncepcji człowieka, na filozofii przyrody ujętej współcześnie, a więc na kosmofilozofii i biofilozofii oraz na zasadach prawa naturalnego.

Jeżeli chodzi o filozoficzną koncepcję człowieka, to należy ją rozpatrywać w ramach jakiegoś systemu filozoficznego. W naszym ujęciu chodzi przede wszystkim o tomistyczną koncepcje człowieka. Koncepcja ta charakteryzuje się niejednolitym rozwiązaniem zagadnień szczegółowych, o czym świadczy bogata literatura ${ }^{62}$ Mimo to można wyróżnić w tej koncepcji elementy stałe, charakterystyczne. Do tych elementów należy zaliczyć:

- strukturę ontyczną bytu ludzkiego,

- jedność psychofizyczną człowieka,

- zasadnicze warstwy struktury człowieka (biologiczną, psychiczną, duchowa),

- immanencje człowieka w przyrodzie i jego transcendowanie przyrody. Strukturą ontyczną czlowieka tworza, zgodnie z tomistyczną koncepcją, materia i forma ${ }^{63}$ lub, inaczej mówiąc, ciało i dusza. ${ }^{64}$ Niezależnie

60 G.B. CARTER, Large Number Boincidences and the Anthropic Principle in Cosmology, w: Confrontation of Cosmological Theories with Observational Date, ed. M.S.Longair, Dordrecht 1974, 291.

61 ŻYCIŃSKI, Zasada antropiczne a teologiczne interpretacje przyrody, 176; por. M. ZABIEROWSKI, Status obserw'atora w' fizyce w'spótczesnej, Wrocław 1990.

62 Por. M.A.KRAPIEC, Ja - czlowiek. Zarys antropologii filozoficznej, Lublin 1974; M.GOGACZ, Cztowiek i jego relacje. Materiaty do filozofii cztowieka, Warszawa 1984; T.WOJCIECHOWSKI, Wybrane zagadnienia z antropologii filozoficznej, Kraków 1985; G. DOGIEL, Antropologia filozoficzna, Kraków 1984; R. le TROCQUER, Kim jestem ja-człowiek? Zarys antropologii chrześcijańskiej, tłum. M. Kaczmarkowski, Paris 1969; E.Coreth, Was ist der Mensch? Grudnzuge einer philosophischem Anthropologie, Innsbruck 1976 (tłum. wloskie, Antropologia filosofica, Brescia 1978); W. PANNENBERG, Kim jest czlowiek? Wspótczesna antropologia n' śietle teologii, tłum. E. Zwolski, D. Szumska, Paris 1978.

63 Por. KRAPIEC, Ja-cztowiek, 101-140.

64 Por. M. GOGACZ, Akt istnienia (ipsum esse) wedtug tomizmu konsekwnetnego, SPhCh 22/ 1986, 2/25-40; tenże, Czlowiek i jego relacje, 5-80. 
od rozwiązywania problemu genezy duszy ludzkiej, ${ }^{65} \mathrm{w}$ tej koncepcji człowieka uwzględnia się z jednakową uwagą wszystkie warstwy struktury człowieka: biologiczną, psychiczną, duchową. W tej filozoficznej koncepcji człowieka kładzie się szczególny nacisk na jedność psycho-fizyczną człowieka oraz na jego immanencję w przyrodzie i na jego transcendowanie przyrody. ${ }^{66}$

Człowiek żyje w środowisku przyrodniczym i społecznym oraz wchodzi w przeróżne związki z elementami tych środowisk.

Ujmowanie środowiska człowieka jako bytu przygodnego odnosi człowieka do bytu koniecznego, a ostatecznie do źródła wszelkiego bytu - do bytu absolutnego, Boga-Stwórcy. ${ }^{67}$

Jeśli człowiek ma efektywnie funkcjonować w społeczeństwie, to filozoficzna koncepcja sozologii musi uwzględniać zasady prawa naturalnego (jeśli nie chce się mówić o prawie zawartym w Dekalogu), a zwłaszcza prawa do życia, prawdy, rodziny, własności ${ }^{68}$

W takiej perspektywie filozoficznej podejmowanie i rozwiązywanie zagadnień sozologicznych pozwala dostrzec $\mathrm{w}$ człowieku podstawową wartość, a atmosferę, hydrosferę, litosferę, kosmosferę, biosferę i antroposferę potraktować jako środowiska, w którym się on rozwija.

\section{4. Systemowa koncepcja sozologii}

Z systemowej koncepcji sozologii wynika systemowe ujęcie zagadnień metateoretycznych i merytorycznych tej nauki. W poprzednich paragrafach wspominaliśmy o tym, określając przedmiot badań, a zwłaszcza wskazując na jego interdyscyplinarny charakter oraz systemowy wymóg

\footnotetext{
ki Por. K. KŁÓSAK, Teoria kreacjonistycznych poczqtków duszy ludzkiej a wspótczesny ewolucjonizm, AC 1/1969/32-56; L.WCIÓRKA, Ewolucja i stw'orzenie. Próba reinterpretacji ewolucji i stworzenia na podstawie romistycznej koncepcji partycypacji, Poznań 1976; T.Wojciechowski, Problem ewolucyjnej genzy duszy ludzkiej. RF 20/1972, 3/149-166; M.GOGACZ, Filozoficzna konieczność istnienia aniolów jako celowych przyczyn dusz ludzkich, w: Człowiek we w'spólnocie Kościota, pod red. L.Baltera, Warszawa 1979, 87-116; J.M. DOLE$\mathrm{GA}$, Kreacjonizm i ewolucjonizm. Ewolucyjny model kreacjonizmy a problem hominizacji, Warszawa 1988; M. Heller, Stworzenie a ewolucja, C 2/1982, 4/58-66.

'6 Por. K. KŁÓSAK, Immanencja i rranscendencja czlowieka w' odniesieniu do przyrody, w: $O$ Bogu i o cztowieku, pod red. B.Bejze, t. 1, Warszawa 1968, 165-177; T. WOJCIECHOWSKI, Transcendencja duszy ludzkiej w ujęciu Piotra Tielharda de Chardin, SPhCh 5/1969, 1/259-262; tenże, Teilhardow'ska koncepcja transcendencji duszy ludzkiej i jej wptyw' na chrześcijańskq antropologię filozoficznq, ŚSHT 7/1974/215-244; J.ŻYCIŃSKI, W poszukiwaniu filozoficznej unifikacji rozwijajqcej klasycznq teze o Bozej immanencji w' przyrodzie, PP 86/1986, 11/169-179; R. INGARDEN, Ksiqzzeczka o człowieku, Kraków 1972, 11-18; A.PÓŁTAWSKI, Roman Ingarden - metafizyk wolności, SF/1990, 2-3/85/98.

Por. GOGACZ, Czlowiek $i$ jego relacje, 82-170.

6. Por. M.A. KRĄPIEC, Cztowiek i praw'o naturalne, Lublin 1975.
} 
stawiany wobec metod stosowanych w tej nauce. Na podstawie naszych dotychczasowych analiz można wnosić, że teoretyczne i praktyczne działania sozologiczne będą wtedy skuteczne, gdy obejmą następujące obszary badawcze:

- antroposfere,

- biosferę,

- atmosferę,

- hydrosferę,

- litosferę,

- kosmosferę.

Wszystkie te obszary tworzą dość złożone systemy, nie mówiąc o swoistej całości, w której rozwija się życie i człowiek.

W systemowej koncepcji sozologii chodzi o ujęcie w jedną całość wszystkich tych obszarów. Całość tę przyjęło się nazywać systemem wielkim. ${ }^{69}$ Termin ten jest pomocny $w$ opisie nie tylko różnorakich podsystemów przyrodniczych, ale również w opisie podsystemów społecznych, ekonomicznych, technicznych, przemysłowych itp. Wielki system to jeden wielki obiekt sterowania.

Wielki system - według M.Lubańskiego ${ }^{70}$ - charakteryzuje się następującymi właściwościami:

- system ten składa się z podsystemów, które można wyróżnić i opisać;

- każdy z podsystemów ma własny cel działania, a jego efektywność może być oceniana w zależności od procesu sterowania;

- cały system ma ogólny cel działania, a jego efektywność ocenia się na podstawie działania podsystemów;

- w podsystemach, jak też między nimi, zachodzą liczne sprzężenia;

- w systemie istnieje hierarchiczna struktura sterowania;

- rozbudowana sieć informacyjna gwarantuje celowe funkcjonowanie i optymalizację systemu;

- w systemie obserwuje się współdziałanie ludzi, maszyn i środowiska przyrodniczego - wszystkie te elementy systemu tworzą środowisko, które (w następstwie) na nie oddziaływuje.

Wymienione cechy wielkiego systemu należy uwzględnić w sozologii jako teoretycznej nauce dotyczącej antroposfery, biosfery, atmosfery, hydrosfery i kosmosfery oraz nauk praktycznych związanych $z$ tą nauka, które rejestrują zagrożenia życia i zdrowia człowieka, starają się im zapobiec i je usunąć. Do takich nauk należy zaliczyć np. sozotechnikę, sozo-

69 Por. Z. KIERZKOWSKI, Elementy informatyki. Technika, metody zastosowania, Warszawa 1976, 498; A.A. LAPUNÓW, Systemy biolgiczne jako systemy wielkie, w: Problemy metodologii badań systemowych, tłum. E.Kaparisi, Warszawa 1973, 149-180.

70 M. LUBAŃSKI, Informacja - system, w: M. HELLER, M. LUBAŃSKI, S.W. ŚLAGA, Zagadnienia filozoficzne wspótczesnej nauki. Wstęp do filozofii przyrody, Warszawa 19822. 29-31; KIERZKOWSKI, Elementy informatyki, 497-498. 
ekonomię, prawo ekologiczne, sozopsychologię, filozofię medycycny.

W systemowej koncepcji sozologii bierze się pod uwagę wiele podsystemów, które mają własne cele działania, ale efektywność ich i ocena tej efektywności zależy od procesu sterowania. Cały wielki system, nazwijmy go technicznie "sozologiczny”, ma ogólny cel działania, którego efektywność zależy od działania podsystemów. Celem tym jest utrzymanie na Ziemi optymalnych warunków życia oraz warunków rozwoju i zdrowia człowieka. Czymś oczywistym jest, że między podsystemami i w nich samych zachodzą liczne sprzężenia. Efektywność takiego systemowego stawiania i rozwiązywania problematyki sozologicznej zależy natomiast od hierarchicznej struktury sterowania oraz od dobrze rozbudowanej sieci informacyjnej.

Systemowa koncepcja sozologii, przyjęta w tej pracy, występuje w sozologicznych badaniach metateoretycznych i merytorycznych. Wydaje się, że jest ona wystarczająco uzasadniona, a ponadto syntetyzuje empiryczną, humanistyczną i filozoficzną koncepcję tej nauki i jest w stanie w sposób zadowalający rozwiązywać problematykę sozologiczną.

\section{Epistemologia sozologii systemowej}

\section{1. Uwagi wstępne}

Przez epistemologię rozumiemy teorię poznania naukowego, zajmującą się poznaniem naukowym w aspekcie jego treści, w odróżnieniu od aspektu formalnego poznania naukowego, którym zajmuje się logika, metodologia i metodyka lub technologia nauki. Tak rozumiana epistemologia polega na zastosowaniu zasad teorii poznania naukowego i na analizowaniu problemów teoriopoznawczych napotykanych w pracy naukowej.

Do zagadnień epistemologicznych sozologii zaliczamy przede wszystkim analizę pojęcia tej nauki, konstrukcję jej definicji, określenie przedmiotu jej badań oraz zaakcentowanie charakterystycznej cechy sozologicznych badań naukowych, a mianowicie ich intedyscyplinarności.

Wyszczególnione zagadnienia może nie stanowią wyczerpującego -zbioru epistemologicznych problemów sozologii systemowej, ale są istotnymi elementami epistemologicznego aspektu struktury poznania naukowego właściwego tej nauce.

\section{2. Pojęcie sozologii systemowej}

Termin „sozologia” pochodzi od greckiego słowa „sodzo", które znaczy „ochraniać", „ratować” „pomagać”. Termin ten do polskiego słownika naukowego wprowadził W. Goetel na początku lat sześćdziesiątych 
XX wieku. Według niego, termin ten oznacza naukę o ochronie przyrody, o ochronie naturalnego środowiska człowieka. Od tego czasu upłynęło ponad trzydzieści lat. Termin „sozologia” został wzbogacony nowymi treściami i tym samym poszerzono jego zakres. Wyrazem tego jest bogata literatura przedmiotowa. ${ }^{71}$ Terminu tego używa się też na określenie nauki o ochronie środowiska.

W analizie pojęcia "sozologia" uwzględniamy dwa aspekty: treściowy i zakresowy. W aspekcie treściowym wskażemy na elementy metodologiczne i przedmiotowe tego pojęcia, natomiast $\mathrm{w}$ aspekcie zakresowym - elementy wyznaczające jego zakres.

W aspekcie metodologicznym² treści pojęcia „sozologia” mówi się przede wszystkim o metodach służących do badań przedmiotu tej nauki. Wyróżnia się tutaj metody empiryczne, humanistyczne, filozoficzne i systemowe. Zagadnienie to będzie szerzej omówione w następnym rozdziale.

W aspekcie przedmiotowym, ${ }^{73}$ dotyczącym treści pojęcia "sozologia", należy wyszczególnić zagadnienia i problemy wchodzące w zakres naukowych badań sozologicznych. Przykładowo można tutaj wymienić takie problemy i zagadnienia jak:

71 A.WODZICZKO, Kierunki wspótczesnej ochrony przyrody, PiT/1935, 4/145-147; tenże, Ochrona przyrody jako nauka i jej potrzeby, CPO 2/1945, 2-3/8-15; W. GOETEL, Sozologia - nauka o ochronie przyrody i jej zasobów, KA 21/1972, 1//31-38; W. MICHAJŁOW, Sozologia a problemy środowiska życia czlowieka, Warszawa 19752; J.M. DOŁEGA, $Z$ zagadnień sozologii, ZZFPiFP 4/1982/328-327; Czlowiek i przyroda, pod red. A. Zdrójkowskiej, Warszawa 1986; Z. WÓJCIK, By ziemia pozostata piękna i zasobna, Warszawa 19863, 20-36; J. EIL-EIBESFELDT, Galapagos. Arka Noego pośród Pacyfiku, thum. Z.Stromenger, Katowice 1982, 255-263.

7 Por. J.I. MARCZUK, Modelowanie matematyczne problemón' środowiska naturalnego, thum. J.Rychlewski, Warszawa 1985; B. GŁOWIAK, Modele obliczeniowe, w: B. GŁOWIAK. E. KEMPA, T. WINNICKI, Podstawy ochrony środowiska, Warszawa 1985, 104126; J. JUDA, Zasady stosowania analizy w ksztattowaniu środowiska, CiŚ cz. 1, 151-180; E. TOMASZEWSKI, Rola obserwacji satelitarnych w ochronie i ksztattowaniu Srodowiska, CiŚ cz. 2, 161-188; B. GLOWIAK, Krażenie zanieczyszczeń w' biosferze i metody tzw. monitoringu, CiŚ cz. 2, 189-224.

73 Por. K. JACNIACKI, Środowisko przyrodnicze i jego ochrona, Warszawa 1989; J.J. SKOCZYLAS, Cywilnopraw'ne środki ochrony środowiska, Warszawa 1986; Cztowiek przeciw'ko sobie, pod red. A.Leńkowej, Warszawa 19862; Z. STROMENGER. Przystosowani pożyja dhuzej, Katowice 1988; G. FLEMING, Klimat - środowisko - czlowiek, tlum. M. Schmidt, Warszawa 1983; Higiena - ochrona zdrowia, pod red. C.W. Korczaka, Warszawa 198410; Ekonomiczne i socjologiczne problemy ochrony środowiska, pod red. A. GinsbertaGeberta, Wrocław 1991; B. FIEDOR. Przyczynek do ekonomicznej teorii zanieczyszczenia $i$ ochrony środowiska, Wrocław 1990; Stres psychiczny w sytuacji kryzysu ekologicznego. Badania z zakresu sozopsychologii, pod red. A. Bieli, Lublin 1984; N.WOLAŃSKI, Populacja ludzka jako bioinduktor stanu środowiska (środow'iskow'e uwarunkowania rozw'oju biologicznego ludności Polski), NP 1/1989/31-56. 
- opis faktyczny stanu przyrody w świecie i w Polsce;

- określenie obiektów, które zanieczyszczają i niszczą środowisko naturalne człowieka;

- przeprowadzenie badań technicznych i technologicznych w celu wprowadzenia urządzeń oczyszczających i technologii nieuciążliwych dla naturalnego środowiska człowieka;

- badanie wpływu zmienionego środowiska na organizmy żywe i na człowieka;

- tworzenie zabezpieczeń prawnych i administracyjnych w skali międzynarodowej i krajowej w celu realizacji programów ochrony naturalnego środowiska człowieka;

- budzenie świadomości moralnej i etycznej wrażliwej na jakość naturalnego środowiska człowieka;

- wychowanie - na różnych szczeblach edukacji narodowej - w duchu wrażliwości na wartość naturalnego środowiska człowieka;

- szukanie środków zmniejszających zanieczyszczenie naturalnego środowiska człowieka i eliminowanie źródeł jego zanieczyszczeń;

- badanie wpływu środowiska naturalnego na stan psychiczny człowieka;

- prowadzenie medycznych badań nowych jednostek chorobowych, powstałych pod wpływem zmienionego środowiska;

- zabezpieczenie "czystych" rezerw genetycznych.

Powyższy wykaz zagađnień i problemów nie jest kompletny, ale w sposób wystarczający ilustruje bogatą i zróżnicowaną treść pojęcia sozologii.

Aspekt zakresowy pojęcia sozologii ${ }^{74}$ obejmuje problemy i zagadnienia dotyczące przyrody nieożywionej i ożywionej oraz antroposfery. Wszystkie te obszary rozpatrywane są $w$ aspekcie ochrony naturalnych właściwości poszczególnych obiektów przyrodniczych i ich wplywu na życie i zdrowie czlowieka. W aspekcie tym, który jest charakterystyczny dla sozologii, mieszczą się badania naturalnych właściwości obiektów nieożywionych i ożywionych oraz ich właściwości powstałych pod wpływem działalności człowieka. Badania te dotyczą również nowo powstałych właściwości środowiska naturalnego i ich wpływu na zdrowie i życie człowieka, a także ich wpływu na kondycję innych gatunków żyjących na ziemi.

74 Por. J. GRĘCZEWSKI, Wptyw pogody na zdrowie człowieka, Warszawa 1972; S.TYSZKA, J.PONIKOWSKA, Czlowiek pogoda klimat, Warszawa 1983; N.W. SKINDER, Chemia a ochrona środowiskam, Warszawa 1991; S.KOZłOWSKI, Ochrona środowiska, w: Człowiek środowisko zdrwon'ie, pod red. J. Kopczyńskiego i A. Sicińskiego, Wrocław 1990, 377383; M. NIKONOROW, Gtówne skażenia ekologiczne żynności, w: tamże, 321-332; J. SOMMER, System praw'a a problemy środowiska i zdrowia, w: tamżę, 365-376. 


\section{3. Defïnicja sozologii systemowej}

W początkowych stadiach powstawania i rozwoju nieomal każdej nauki występują trudności z jej definiowaniem. Również sozologia nie wyszła jeszcze $z$ początkowej fazy rozwoju, mimo że problematykę ochrony przyrody podejmowano już w XIX wieku, to jednak nadal boryka się on $\mathrm{z}$ podobnymi trudnościami.

Z zastanych definicji sozologii wybieramy dwie, podane przez W.Michajłowa:

D1 „Sozologia, nauka o ochronie przyrody, zajmuje się przyczynami, doraźnymi skutkami oraz dalszymi następstwami przemian zachodzących w wyniku działalności gospodarczej i społecznej człowieka zarówno w naturalnych, jak i uprzednio odkształconych układach przyrodniczych na mniejszym lub większym obszarze biosfery. Zakresem swym obejmuje skuteczne sposoby zapobiegania ujemnym dla społeczeństw następstwom działalności człowieka w środowisku naturalnym bądź przynajmniej wskazuje możliwości maksymalnego ich złagodzenia."75

D2 "Sozologia jest nauką o przyczynach i doraźnych skutkach, a także dalszych następstwach przemian zachodzących zarówno w naturalnych, jak i uprzednio już odkształconych układach przyrodniczych na mniejszym lub większym obszarze biosfery w wyniku działalności społecznej i gospodarczej człowieka oraz skutecznych sposobach zapobiegania jej ujemnym następstwom dla społeczeństw lub przynajmniej o możliwościach maksymalnego ich złagodzenia." 76

Podane powyżej definicje sozologii są bardzo rozbudowane i w sposób szczegółowy określają przedmiot, zadania i zakres badań tej nauki. Określenia te sugerują, że sozologia ma charakter interdyscyplinarny, co determinuje wybór i konstruowanie metod badawczych stosowanych $\mathrm{w}$ tej nauce. W definicjach tych nie zwraca się jednak uwagi na potrzebę ujęć całościowych w badaniach sozologicznych.

W niniejszej pracy proponujemy następująca definicję sozologii:

D3 Sozologia jest nauką o systemowej ochronie biosfery przed destrukcyjnym oddziaływaniem na nią antroposfery.

Wyjaśnień wymagają następujące, użyte w definicji, wyrażenia: „systemowa ochrona”, „biosfera”, „antroposfera”, „destrukcyjne działanie”.

"Systemowa ochrona" - wyrażenie to wiąże się z systemowym podejściem do badań naukowych, które charakteryzują się całościowym ujęciem problematyki i zarazem wskazują na sprzężenia zwrotne zachodzą-

75 W. MICHAJŁOW, Sozologia - nauka o ochronie i ksztaltowaniu środowiska, w: Nowe specjalności w' nauce w'spótczesnej, pod red. T. Kotarbińskiego, W. Osińskiej, E. Geblewicza, Wrocław 159.

76 MICHAJŁOW, Sozologia i problemy środowiska życia czlonieka, 50. 
ce między elementami wewnątrz systemowymi i między systemem a jego otoczeniem. Przez system ${ }^{77}$ rozumiemy zespół różnych elementów wzajemnie ze sobą powiązanych, na siebie oddziaływujących i stanowiących pod pewnym względem całość. Określenie to nawiązuje do filologicznego znaczenia terminu "system" (gr. systema) i podkreśla taki układ elementów, który tworzy pewną całość uwarunkowaną stałym ładem jego części składowych w świecie realnym lub w sferze poznania ludzkiego. System stanowi całość, w której elementy są powiązane $z$ sobą relacjami oddziaływania i stanowia jego strukturę. Każdy system otwarty ma swoje otoczenie. W przyrodzie i w poznaniu ludzkim występują przede wszystkim systemy otwarte. Otoczenie jest to rzeczywistość, która wchodzi lub może wchodzić w relacje z systemem. Zatem „systemowa ochrona" biosfery oznacza całościowe i wszechstronne działanie człowieka na rzecz ochrony przyrody w sferze nauki, techniki, technologii, pedagogiki i dydaktyki.

Termin „biosfera”78 oznacza przestrzeń zamieszkaną przez organizmy żywe. Przestrzeń ta obejmuje następujące obszary:

- powierzchnie ziemi i jej górna warstwę, około $2-3 \mathrm{~km}$ w głąb litosfery (głębiej w skorupie ziemskiej spotyka się tylko bakterie);

- dolną część atmosfery, do wysokości kilkuset metrów (wyżej unoszą się $\mathrm{w}$ atmosferze bakterie, zarodniki i bardzo małe owady);

- całą hydrosferę, czyli wszystkie wody znajdujące się na kuli ziemskiej. Szczegółową analizę tego pojęcia przeprowadzamy w rozdziale Biosfera.

Termin „antroposfera” oznacza całą przestrzeń różnorakiej działalności człowieka, a więc gospodarczej, społecznej, kulturalnej, politycznej, naukowej, twórczej, i wytwórczej. Szczegółowej analizie poddaliśmy to pojęcie w rozdziale Antroposfera.

77 Por. Maty słow'nik terminón' i pojęć filozoficznych, oprac. A.Podsiad, Z.Więckowski, Warszawa 1983; 380-381; Stownik wyrazów obcych, red. naukowy J.Tokarski, Warszawa 1971, 723; J. BOCHEŃSKI, O systemie. Wykład wygłoszonych w ATK 1987-11-05, SPhCh 24/1988, 2/235-248; Problemy metodologii badań systemowych, tłum. E.Kaparisi, Warszawa 1973; S. MŁYNARKI, Elemnty teorii systemów i cybernetyki. Warszawa 1974; Ogólna teoria systemów, pod. red. G.J. Klira, tłum. C. Bergman, Warszawa 1976; W.SADOWSKi, Podstaw'y ogólnej teorii systemów: Analiza logiczno-metodologiczna, tłum. A.Lewicka, Warszawa 1978; L. von BARTALANFFY, Ogólna teoria systemów: Podstawy, rozwój, zastosow'ania, tlum. E.Waydyłło-Woźniak, Warszawa 1984; M. LUBAŃSKI, Informacja - system, w: M. HELLER, M. LUBAŃSKI, S.W. ŚLAGA, Zagadnienia filozoficzne w'spótczesnej nauki, Warszawa 1982, 14-70; Nauka - technika - system, pod red. W. Gasparskiego i D. Miller, Wrocław 1981.

78 Por. Biosfera i jej zasoby, thum. S. Rajpert, L. Biegański, Warszawa 1976; Kleine Enzyklopadie. Leben, HRSG.: E. Geissler, E. Libbert, J. Nitschmann, G. Thomas-Petersein, Leipzig 1978, 13; Biosfera, red. A. Witkowska, tłum. B. Molski, Warszawa 1973. 
Wyrażenie "destrukcyjne oddziaływanie" oznacza całą działalność człowieka, która wchodzi w konflikt $\mathrm{z}$ biosferą, która zmienia naturalne środowisko życia oraz powoduje strukturalne zmiany genetyczne niektórych roślin i zwierząt, w tym również człowieka; ma ona również wpływ na chemiczną i biologiczną równowagę w biosferze.

\section{4. Przedmiot i zakres badań sozologii systemowej}

Przedmiotem badań sozologii w sensie ogólnym jest wzajemne oddziaływanie biosfery i antroposfery. $W$ języku tradycyjnym jest to materialny przedmiot tej nauki. Natomiast formalnym przedmiotem badań sozologii jest ochrona biosfery przed destrukcyjnym działaniem na nią antroposfery. Ten aspekt ochrony czy osłony stanowi o specyfice sozologii i jej odrębności od innych nauk o biosferze i antroposferze.

Zakres badań sozologii obejmuje - przy takim scharakteryzowaniu jej przedmiotu - przyrodę nieożywioną i ożywioną, przez którą się rozumie kosmo-bio-geograficzne środowisko życia, ulegające pod wpływem oddziaływania antroposfery wielorakim zmianom, a czasem calkowitej destrukcji.

W zakres tak pojmowanego przedmiotu badań sozologii wchodzą rośliny i zwierzęta, ich struktury genetyczne i prawidłowy rozwój, a także zakłócenia rozwojowe spowodowane działaniem antroposfery. Do zakresu badań sozologicznych należy też środowiska fizyczne, w którym tkwi biosfera, a mianowicie atmosfera, hydrosfera, litosfera i kosmosfera.

Po tym ogólnym omówieniu przedmiotu badań sozologii należy wyszczególnić zagadnienia podejmowane w ramach sozologicznych badań naukowych. Zagadnienia te mieszczą się w zakresie badań sozologii oraz dotyczą biosfery i antroposfery, a także zachodzących między nimi relacji.

Wśród zagadnień dotyczących biosfery należy wymienić problemy natury biologicznej i biologiczno-genetycznej. Zadania związane $z$ tą problematyką sprowadzają się do opisu aktualnego stanu biosfery uwzględniającego jej środowiska: atmosferyczne, wodne, geologiczne, a nawet kosmiczne.

Do zagadnień sozologicznych, związanych ze zjawiskami antroposfery, należą problemy dotyczące stanu biologicznego i biologiczno-medycznego populacji ludzkich w poszczególnych krajach i na całych kontynentach oraz problematyka, która wyłania się wraz z rozwojem sozotechniki, ${ }^{79}$ sozop-

79 Por. Sozologia i sozorechnika, red. W.Goedel, ZNAGH 21/1971/ zeszyt specjlany; B. GŁOWIAK, J. PECYNA, Technologia oczyszczania gazów odlotowych, w: GŁOWIAK, KEMPA, WINNICKI, Podstawy ochrony środowiska, 129-156. 
sychologii, ${ }^{80}$ sozoekonomii, ${ }^{81}$ prawa ekologicznego, ${ }^{82}$ etyki ekologicznej. ${ }^{83}$

W związku z destrukcyjnymi oddziaływaniami antroposfery na biosferę wskazuje się na wielorakie problemy pojawiające się w związku z następującymi zagrożeniami:

- fizycznego środowiska biosfery (powietrze, woda, gleba);

- środowiska biologicznego;

- życia i zdrowia człowieka;

- życia w małych, średnich, dużych i wielkich makroregionach;

-- poszczególnych populacji, a nawet całych gatunków czy ras, zarówno w faunie, jak i florze;

- krajobrazu, zgrupowań roślin i zwierząt.

Biorąc to wszystko pod uwagę, należy jeszcze raz podkreślić, że przedmiotem badań sozologii jest wpływ działalności człowieka na przyrodę oraz metody jej ochrony.

\section{Metodologia sozologii systemowej}

\section{1. Nota wprowadzająca}

Przedstawiony w tym rozdziale materiał nie pretenduje do ostatecznego rozstrzygnięcia wszystkich problemów związanych z metodologią sozologii. Chodzi raczej o ich wyraźne postawienie i sformułowanie. Przede wszystkim należy zauważyć, że nie można wskazać na jakąś jedną, charakterystyczną metodę stosowaną w sozologii, gdyż jej interdyscyplinarny charakter zmusza ją do korzystania z wielu metod: empirycznych, humanistycznych, filozoficznych i systemowych. Grupy tych metod wyznaczaja treść poszczególnych paragrafów niniejszego rozdziału.

80 Por. Stres psychiczny w' sytuacji kryzysu ekologicznego. Badania z zakresu sozopsychologii, pod red. A.Bieli, Lublin 1984.

81 Por. K. LESZCZYŃSKI, Rachunek spoteczno-ekonomiczny w ochronie środowiska naturalnego, CiŚ cz. 1, 95-116; T. WINNICKI, Ekonomiczne problemy ochrony środowiska, Głowiak, Kempa, Winnicki, w: Podstaw'y ochrony środowiska, 323-336; K. ZABIEROWSKI, Ekonomiczne podstawy ochrony przyrody, w: Ochrona przyrodmiczego śodowiska cztowie$k a$, pod red. W. Szafera, Warszawa 1973, 363-386.

$\$ 2$ Por. W. BRZEZIŃSKI, Problematyka prawna ochrony środon iska, CiS cz. 1, 117-150; Skureczność prawa ochrony środowiska w' warunkac'h reformy gospodarczej, pod red. J.Sommera, Wrocław 1990; Prawo czlowieka do środowiska naturalnego, pod red. J.Sommera, Wrocław 1987.

83 Por. T. ŚLIPKO, Granice życia. Dylematy w'spótczesnej bioetyki, Warszawa 1988, 22-75; J.ALEKSANDR WICZ, Sumienie ekologiczne, Warszawa 19852; F. WORONOWSKI, Ewangelizacja porzq̨dku doczesnego, Łomża 1990, 142-159.; tenże, Ojczyzna oczekiwana, Lomża 1991, 152-154. 


\section{2. Empiryczne metody w sozologii systemowej}

Do podstawowych metod stosowanych w naukach empirycznych należy zaliczyć obserwację naukową, która może być bezpośrednia i pośrednia, a nadto ilościowa i jakościowa. Podobne obserwacje prowadzi się także w sozologii ${ }^{84}$ a mianowicie:

- bezpośrednia obserwacja za pomocą naturalnych władz poznawczych;

- pośrednia obserwacja za pomocą różnych przyrządów i skomplikowanej aparatury badawczej;

- bezpośrednią obserwację ilościową zmian $\mathrm{w}$ środowisku lub $\mathrm{w}$ organizmach;

- bezpośrednią obserwację jakościową zmian w środowisku i w organizmach ocenianych jako zmiany zaawansowane, czyli jakościowe;

- pośrednią obserwację ilościową zmian ilościowych środowiska i organizmów rejestrowanych za pomocą mierników ilościowych;

- pośrednią obserwację jakościową, która na podstawie zmian ilościowych $\mathrm{w}$ środowisku i w organizmach wnosi o dokonujących się $\mathrm{w}$ nich zmianach jakościowych.

W sozologii prowadzi się nadto następujące obserwacje naukowe: satelitarne, ${ }^{85}$ monitoringowe, ${ }^{86}$ laboratoryjne. ${ }^{87}$

Obserwacje satelitarne pozwalają rejestrować zanieczyszczenia na dużych obszarach kuli ziemskiej. Obserwacje te, mimo że należą do metod współczesnych, mają już swoją historię, w której możemy wyróżnić trzy okresy. Pierwszy (początkowy) jest związany $\mathrm{z}$ wykonywaniem zdjęć $\mathrm{z}$ rakiet balistycznych i balonów; obejmuje lata 1946-1961 (metody te nie zostały jeszcze całkowicie zarzucone). Drugi (eksperymentalny) wyróżnia

84 Por. K. AJDUKIEWICZ, Metodologiczne typy nauk, w: tenże, Język i poznanie. Wybór pism, t. 1, Warszawa 1985, 295-296; tenże, Subiektywnośc i niepowtarzalność metody bezpośredniego dośniadczenia, w: tamże, t. 2, Warszawa 1985, 371-373; tenże, Logika pragmatyczna, Warszawa 1965, 227, 228, 332, 337; Z. ZIEMBIŃSKI, Logika praktyczna, Warszawa 197711, 151-152; S. PABIS, Metodologia i metody nauk empirycznych, Warszawa 1985, 59-63; A. MENNE, Wprowadzenie do metodologii. Elementarne ogólne metody pracy naukowej w zarysie, tlum. M. Bombik, ML 3/1985/108-109; M. HELLER, Teoretyczne podstaw'y kosmologii, Warszawa 1988, 104-112, 127-134; Filozofia a nauka, red. M. IŻEWSKA, Wrocław 1987, 433-444.

85 Por. B.W. WINOGRADOW, Satelitarne metody badania Środowiska przyrodniczego, thum. A.T. Jankowski, Warszawa 1983.

86 Por. B. GLOWIAK, E. KEMPA, T. WINNICKI, Podstawy ochrony środowiska, Warszawa 1985, 84-126; B. GLOWIAK, Rola monitoringu w ochrone środowiska, w: tamże, 93-104; N.W. SKINDER, Chemia a ochorna środowiska, Warszawa 1991, 45-53.

87 Por. Fizykochemiczna analiza zanieczyszczeń powietrza, pod red. A.Szaynoka, Wrocław 1990; J.GRZYBOWSKA, Zanieczyszczenia chemiczne. Oddzialywanie czynników w'spótczesnego środowiska na organizm cztowieka, Warszawa 1974; Z. PRZE•DZIECKI, Biologiczne skutki cheminizacji środowiska, Warszawa 1980. 
próby ze zdjęciami i obrazami satelitarnymi podejmowane w latach 19601972; w tym czasie maleje liczba prac eksperymentalnych, a wzrasta liczba prac praktycznych. Trzeci (naukowy i praktyczny) trwa do dzisiaj, a charakteryzuje się wykorzystaniem informacji z obserwacji satelitarnych.

Obserwacje sozologiczne dokonuje się $\mathrm{z}$ następujących pojazdów satelitarnych:

- z rakiet balistycznych (wysokość lotu orbitalnego wynosi od 80 do $150 \mathrm{~km}$ );

- z załogowych statków kosmicznych i z załogowych stacji orbitalnych (wysokość lotu wynosi od 150 do $600 \mathrm{~km}$ );

- ze sztucznych satelitów Ziemi (wysokość lotu wynosi od 600 do $2000 \mathrm{~km}$ );

- $\mathrm{z}$ automatycznych i załogowych stacji międzyplanetarnych (planowany zasięg lotu od 60000 do $150000 \mathrm{~km}$ );

- z księżycowego obserwatorium geofizycznego (zasięg $400000 \mathrm{~km}$ ). Materiały otrzymywane z powyższych obserwacji charakteryzują się następującymi cechami:

- integracją horyzontalną polegająca na zarejestrowaniu na jednym obrazie rozległych obszarów;

- integrację pionową polegająca na zarejestrowaniu na jednym obrazie różnych komponentów geosfery (np. atmosfery, hydrosfery, litosfery, biosfery i antroposfery);

- integracją dynamiczną polegająca na zastosowaniu jednolitego syste$\mathrm{mu}$ rejestrującego $\mathrm{w}$ kolejnych zobrazowaniach danego obszaru $\mathrm{w}$ określonych przedziałach czasowych.

Ponadto należy zauważyć, że rozwój badań satelitarnych Ziemi pozwolił udoskonalić ich technikę i metodykę, a mianowicie:

- określić warunki techniczne wykonywania obrazów satelitarnych (rozdzielczość przestrzenna i spektralna aparatury pomiarowej); uwzględniać sferyczność Ziemi przy przetwarzaniu zobrazowań satelitarnych; dobierać odpowiednie widma elektromagnetyczne do rejestracji przez daną aparaturę; opracować najlepsze sposoby pozyskiwania informacji i jej kodowania oraz przechowywania;

- określić przyrodnicze warunki zobrazowań satelitarnych (zakresy spektralne, zachmurzenia, koncentracja aerozoli i ich czasowo-przestrzenny rozkład, właściwości pochłaniania oraz emisyjność różnych obiektów, zjawiska przyrodnicze i ich cykliczność przestrzenno-czasowa);

- udoskonalić metodykę interpretacji; określić zasady generalizacji optycznej, geometrycznej i tematycznej; otrzymywać małoskalowe zobrazowania satelitarne, uzyskiwane po raz pierwszy na testowych poligonach $\mathrm{w}$ czasie przeprowadzania zespolonych eksperymentów geofizycznych; ustalić metodykę wzorcowania i ekstrapolacji danych; wykorzystywać dane w nauce i praktyce; opracować ilościowe i automatyczne metody przekazywania informacji oraz tworzyć satelitarne podsystemy geoinformacyjne. 
Zarysowana problematyka metodologiczna związana $\mathrm{z}$ naukową obserwację satelitarną Ziemi jest przedmiotem zainteresowania wielu autorów $\mathrm{z}$ różnych dyscyplin i stanowi podstawę interdyscyplinarnych i międzynarodowych badań sozologicznych środowiska ziemskiego.

Monitoring należy do szczególnego rodzaju obserwacji naukowej, która pozwala na integrację wyników, a przy automatycznym przekazie informacji i jej rejestracji komputerowej - także na błyskawiczną informację o stanie środowiska $\mathrm{w}$ wielu aspektach oraz szybką ocenę i diagnozę.

Analizy laboratoryjne powietrza, wody i gleby służą za podstawę rozpoznawania aktualnego środowiska życia, a badania laboratoryjne organizmów i człowieka pozwalają na ocenę stanu tych organizmów oraz przewidywanie trendów adaptacyjnych $w$ organizmach do zmieniającego się środowiska. Spośród szczegółowych metod tu stosowanych należy wymienić:

- metody spektroskopowe (optyczne) związane $z$ oddziaływaniem promieniowania na materię, np. spektrofotometria absorpcyjna $w$ świetle widzialnym i $\mathrm{w}$ nadfiolecie, spektrofotometria $\mathrm{w}$ podczerwieni, absorpcyjna spektrofotometria atomowa, spektralna analiza emisyjna, turbidymetria i nefelometria;

- metody elektrochemiczne służące badaniu efektów towarzyszących przepływowi prądu przez badany roztwór lub spowodowanych reakcjami na elektrodach zanurzonych $w$ roztworze, np. potencjonometria, elektroliza, klometria, polarografia, konduktometria;

- metody chromatograficzne polegające na rozdzielaniu badanych mieszanin $\mathrm{w}$ układzie stacjonarnym i ruchomym oraz oznaczaniu ich składników dowolną metodą;

— inne metody, np. radiacyjne, aktywacyjne, objętościowe;

- metody wykorzystywane w ustalaniu podstawowych zanieczyszczeń powietrza:

- metoda gazometryczna pomiaru zawartości $\mathrm{CO}$ i $\mathrm{CO} 2$,

- metoda konduktometryczna,

- metoda analizy w podczerwieni,

- metoda kolorymetryczna,

- metoda jodometryczna,

- metoda siarczanów i kwasu siarkowego,

- metoda oznaczania tlenków azotu za pomocą elektrody jonoselektywnej (metoda pośrednia),

- metoda potencjometryczna $z$ użyciem elektrody jonoselektywnej,

- metoda oznaczania benzenu w powietrzu bez wzbogacania próbki,

- metoda oznaczania benzenu w powietrzu z wzbogaceniem próbki,

- metoda oznaczania składu jakościowego mieszaniny węglowodorów,

- metoda oznaczenia par acetonu w powietrzu (spektrofotometria $w$ podczerwieni), 
- metoda kolorymetryczna oznaczania ozonu,

- metoda zawartości chlorowodoru w powietrzu;

- metody pozwalające określić właściwości fizykochemiczne pyłu:

- oznaczanie gęstości pyłu,

- analiza ziarnowa pyłu.

- oznaczanie metali alkalicznych i ziem alkalicznych metodą fotometrii płomieniowej,

- oznaczanie zawartości Cu i Cr metodą absorpcji atomowej,

- metody pomiaru zapylenia gazów przemysłowych,

- metody pomiaru opadu pyłów.

Na szczególna uwagę w obserwacji naukowej zasługuje "pomiar”. ${ }^{88}$ Istotą naukowych obserwacji ilościowych jest pomiar, którego wartość zależy od aparatury pomiarowej. Wynik pomiaru może być zarejestrowany w sposób pośredni, czyli automatyczny, lub w sposób bezpośredni przez prowadzącego badania naukowe.

$\mathrm{Na}$ podstawie prowadzonych obserwacji naukowych dokonuje się opisu, ${ }^{89}$ którego wartość zależy od rzetelności prowadzonej obserwacji oraz od użytej terminologii charakterystycznej dla danej dziedziny naukowej. W naszym przypadku zawsze chodzi o terminologię z zakresu sozologii. Opis ten w końcowym rezultacie tworzy, w pewnym znaczeniu, fakt naukowy, ${ }^{90}$ który stanowi podstawę budowania teorii wyjaśniających, wartościujących i sprawozdawczych.

W tym miejscu należy podkreślić znaczenie aparatury ${ }^{91}$ pomiarowej w prowadzonych naukowych obserwacjach ilościowych w zakresie badań sozologicznych. Aparatura ta pozwala na rejestrację zmian ilościowych w naturalnym środowisku życia oraz zmian ilościowych w organizmach żywych, zwłaszcza w człowieku. Wymagana jest coraz "czulsza" aparatura pomiarowa, to znaczy rejestrująca nawet najmniejsze ilości szkodliwych substancji dla życia.

88 Por. K. AJDUKIEWICZ, Pomiar, w: tenże, Język $i$ poznanie, t. 1, 356-364; J.I. MARCZUK, Modelowanie matematyczne środowiska naturalnego, thum. J.Rychlewski, Warszawa 1985; A. STARUSZKIEWICZ, O metodzie naukowej, w: Nauka $i$ informacja, por. red. J.MIśka, Kraków 1987, 55-61; Z.Cackowski, Obserwacja, w: Filozofia a nauka, 441.

89 Por. T. CZEŻOWSKI, O metodzie opisu analitycznego, w: tenże, Odczyty filozoficzne, Toruń 19692,136-142; A. MENNE, Wprowadzenie do metodologii, 112-113; K. AJDUKIEWICZ, Jezyk i poznanie, t. 2, 34, 408; A. MOTYCKA, $O$ osobliwosci opisu w nauce, SE 1/1990/ 227-248.

90 Por. C.G. HEMPEL, Podstawy nauk przyrodniczych, thum. B.Stanosz, Warszawa 1968, 2327; K. KŁÓSAK, Z teorii i metodologii filozofii przyrody, Poznań 1980, 124-126, 133-136; S. MAZIERSKI, Prolegomena do filozofii przyrody inspiracji arystotelosowsko-tomistycznej, Lublin 1968, 31-39, 63-82; S. KAMIŃSKI, Pojęcie nauki i klasyfikacja nauk, Lublin 19813, 103, 170, 172.

91 Por. J. SUCH, Eksperyment, w: Filozofia a nauka, 120-131; Cackow'ski. Obserw'acja, w: Filozofia a nauka, 441. 


\section{3. Humanistyczne metody w sozologii systemowej}

Sozologia musi uwzględnić także niektóre metody nauk humanistycznych lub przyrodniczo-matematycznych. W obszarze badań sozologicznych, w którym trzeba stosować tego rodzaju metody, znajduje się człowiek, jego stan biologiczny i psychiczny, jego działalność gospodarcza w zagrożonym środowisku oraz aspekty etyczno-moralne wszelkiej aktywności ludzkiej.

W badaniach sozologicznych dotyczących sytuacji człowieka w zagrożonym środowisku należy brać pod uwage wiele metod psychologicznych i etnopsychologicznych, nie wykluczając introspekcji, ponieważ $w$ badaniach tych nie sposób całkowicie pominąć doświadczenia wewnętrznego. Przy odczytywaniu testów, kwestionariuszy, ankiet należy posługiwać się zatem również metodami rozumienia i interpretacji wypowiedzi osób badanych. ${ }^{92}$

Do charakterystycznych metodologicznych cech nauk humanistycznych należy zaliczyć rozumienie, intuicyjne ujęcie całości i ocenę wartości. ${ }^{93} \mathrm{~W}$ naukach tych $\mathrm{K}$. Ajdukiewicz ${ }^{94}$ wyróżnia trzy metodologiczne typy postępowania, a mianowicie:

- wyjaśniający lub nomotetyczny;

- wartościujący lub aksjologiczny;

- sprawozdawczy lub idiograficzny.

Typ wyjaśniający lub nomotetyczny (nomos - prawo) charakteryzuje zarówno nauki humanistyczne, jak i przyrodnicze, a polega na zbieraniu faktów naukowych, odkrywaniu praw i wyjaśnianiu ich za pomocą zasad i hipotez oraz na konstruowaniu teorii wyjaśniających rozleglejsze dziedziny wyznaczane przez tego rodzaju fakty.

92 Por. J. PIETER, Przedmiot $i$ metoda w' psychologii, Wrocław 1963, 126-147; tenże Sporne problemy psychologii, Warszawa 1969, 124-252; Z. SKORNY, Wspótczesne metody badań psychologicznych, Wroclaw 1966; A.GORALSKI, Metody opisu i wnioskowania w psychologii, Warszawa 1974; J. BIELECKI, Wybrane zagadnienia psychologii, Warszawa 1986, 810; tenże, Osobowośc mtodzieży niepetnosprawnej z zaburzeniami w'zroku, stuchu, ruchu $i$ mowy, Warszawa 1990, 110-139; J. KOŚCIUCH, Projekcyjne metody badania osobowości, Warszawa 1990; K. OSTROWSKA, D. WÓJCIK, Teorie kryminologiczne, Warszawa 1986. 133-223; Studia z psychologii, pod red. K.Ostrowskiej, t. 2, Warszawa 1990, 20-25, 72-88, 105-114, 130-138, 154-170; S.SIEK, Higiena psychiczna i autopsychoterapia, Warszawa 1982; tenże, Struktura osobon'ości, Warszawa 1986; M. LUBAŃSKI, Analogia a interpretacja, SPhCh 25/1989, 1/209-220.

93 Por. T. CZEŻOWSKI, $O$ naukach humanistycznych, w: tenże, Odczyty filozoficzne, 38-39; AJDUKIEWICZ, Metodologiczne typy nauk, 306-307; S. KAMIŃSKI, Typy ludzkiej wiedzy, w: tenże, Jak filozofować? Studia z metodologii filozofii klasycznej, do druku przygotował T.Szubka, Lublin 1989, 13-32.

94 AJDUKIEWICZ, Metodologiczne typy nauk. 309-310; por. CZEŻOWSKI, O naukach humanistycznych, w: tenże, Odczyty filozoficzne, 36-38; KAMIŃSKI, Pojęcie nauki i klasyfikacja nauk, 166-173 
Typ sprawozdawczy lub idiograficzny (idios - jednostkowy, swoisty) polega na rozpoznawaniu faktów jednostkowych jako takich, zdaniu sprawy z tych faktów i ich opisaniu w ich konkretnej postaci; nie dąży się tu do odkrycia praw rządzących faktami.

Typ wartościujący lub aksjologiczny jest właściwy naukom humanistycznym. Najważniejszymi pojęciami humanistyki są pojęcia aksjologiczne, jak prawda, piękno, dobro. Ten typ postępowania metodologicznego przysparza wielu trudności, ponieważ musi on uwzględniać różne systemy wartości i na podstawie jednego z nich oceniać badany przedmiot.

\section{4. Filozoficzne metody w sozologii systemowej}

Ciaggle aktualnym problemem $w$ metodologii filozofii jest wypracowanie stosownych metod dla poszczególnych dyscyplin filozoficznych. Badania prowadzone $\mathrm{w}$ tym zakresie dostarczają bogatego materiału analizom metodologicznym..$^{95}$ Należy tutaj wspomnieć przede wszystkim o analizie filozoficznej, w której możemy wyróżnić dwa typy. Pierwszy typ jest analizą ontologiczną w znaczeniu ścisłym, stosowaną w filozofii bytu. Drugi typ jest analizą skierowana na taki rodzaj bytu, który występuje $w$ przyrodzie, czyli na byt materialny. Nie podejmujemy się $w$ tym miejscu zadania zreferowania dyskusji na temat analizy ontologicznej $w$ znaczeniu szerszym $\mathrm{i}$ jej implikacji ontologicznych o charakterze redukcyjnym, a jedynie pragniemy wspomnieć o znaczącej roli, jaką w tej dyskusji odegrał Kazimierz Kłósak, ${ }^{96}$ który pierwszy zadał sobie trud wypracowania metodologii filozofii przyrody; należałoby również wspomnieć o dorobku naukowym Mieczysława Alberta Krąpca ${ }^{97}$, Stanisława Kamińskiego i Edmunda Morawca ${ }^{98}$ w zakresie metodologii filozofii bytu $\mathrm{i}$ innych dyscyplin filozoficznych.

95 Por. KAMIŃSKI, Osobliwość metodologiczna teorii bytu, w: tenże Jak filozofować?, 71-88; tenże, $Z$ metafilozofii cztowieka, w: tamże, 249-262; tenże, O metodologicznej autonomii ety$k i$, w: tamże, 321-330; E. MORAWIEC, Rola intuicji w przyjmowaniu zatożeń w' metafizyce ogólnej u J.Maritaina, Warszawa 1974; tenże, Poczq̨tkowa postać wiedzy racjonalnej o przyrodzie, SPhCh 26/1990, 1/61-78; tenże, Poczq̨kowa postać empirystycznej i apriorystycznej wiedzy o świecie, SPhCh 26-1990, 2/7-22; M. GOGACZ, Wychowanie filozoficzne, SPhCh 27/1991, 1/159-166; tenze, Podstawy odmian koncepcji Boga, SPhCh 27/1991, 2/7-18. Por. KŁÓSAK, Z teorii i metodologii filozofii przyrody, 79-80, 94, 105-106, 150-151.

97 Por. M.A. KRĄPIEC, Metafizyka - ale jaka?, STNKUL 11/1960/64-72; tenże, Metody w'spólczesnej metafizyki, RF 14/1968, 1/5-40; tenże, Osobliwość metodologiczna teorii bytu, RF 27/1979, 2/33-5; tenże, Metodologiczne typy etyki, w: tenżę, Jak filozofować?, 307-320. Por. S. KAMIŃSKI, Rola dedukcji w meta fizyce, STNKUL 11/1960,64-72; tenże, Metody wspótczesnej metafizyki, RF 14/1968, 1/5-40; tenże, Osobliwość metodologiczna teorii bytu, RF 27/1979, 2/33-50; tenże, Metodologiczne typy etyki, w: tenże, Jak filozofować? 307-320. 
Do rozwiązywania zagadnień i problemów sozologicznych musimy wykorzystywać analizę ontologiczną w znaczeniu szerszym i w znaczeniu ścisłym, jeśli nie chcemy poprzestać na wyjaśnieniach, jakie można uzyskać $w$ językach i za pomocą teorii nauk empirycznych, lecz usiłujemy zrobić krok naprzód, tzn. zinterpretować naukowe fakty sozologiczne $w$ świetle filozofii, czyli przełożyć ich naukową prezentację na język filozofii i w ramach tych teorii wyjaśniać wspomniane fakty, tak żeby sprostać wymaganiom filozofa i powiązać je $\mathrm{z}$ kategoriami bytu występującego $\mathrm{w}$ przyrodzie.

W naukowych badaniach sozologicznych, podobnie jak w każdym typie badań naukowych, problem prawdy, a więc jej koncepcji, definicji, i kryteriów, jest szczególnie ważny. W badaniach tych, opierając się na klasycznej definicji prawdy, ${ }^{99}$ dąży się do uzyskiwania i przekazywania prawdziwych informacji naukowych, decydujących o właściwej ocenie stanu biosfery i antroposfery oraz podjęciu ewentualnych środków zaradczych. Informacja prawdziwa, dotycząca stanu biosfery i antroposfery, oraz jej przekaz są jednymi z podstawowych wymogów etycznych obowiązujących naukowców, a więc także badaczy życia i jego środowiska. Do problematyki filozoficznej wrócimy w końcowych fragmentach pracy, przy omawianiu zagadnienia antroposfery.

\section{5. Systemowe metody $w$ sozologii systemowej}

We współczesnych teoriach nauki, funkcjonujących $w$ nurcie filozofii tomistycznej, należy wyróżnić systemową teorię nauki, którą formułuje się na podstawie ogólnej teorii systemów i jej zastosowań. ${ }^{100}$ Należałoby tu uwzględnić przede wszystkim prace M.Lubańskiego ${ }^{101}$ i S.W.Ślagi ${ }^{102}$

99 Por. K. TWARDOWSKI, o tak zwanych prawdach względnych, w: tenże, Wybrane pisma filozoficzne, Warszawa 1965, 315-336; A.B. STĘPIEN, Wartości poznawcze w' ujęciu n'spótczesnej filozofii tomistycznej, SF /1983, 1-2/49-83; H. ROSNEROWA, Wspótczesne spory o pojęcie prawdy i jej ekspresję, Z 27/1975/1243-1261; W. KRAJEWSKI, O pojeciach praw'dy względnej, SF /1963, 3-4/211-220; J. WOLEŃSKI, O semantycznej definicji praw'dy, SE 1/1990/67-120; M.I. EOJEWSKA, Filozofia nauki, Warszawa 1986, 107-116.

100) Przykładowo wymieńmy następujące pozycje: Problemy metodologii badań systemowych, thum. E. Kaparisi, Warszawa 1973; Ogólna teoria systemów', pod red. G.J. Klira, thum. C. Bergman, Warszawa 1976; L. von BARTALANFFY, Ogólna teoria systemów: Podstawa, rozwój, zastosowania, tłum. E.Woydyłlo-Woźniak, Warszawa 1984; A. LATAWIEC, Symulacja zjawisk biologicznych widzina systemowo, SPhCh 26/1990, 2/37-54.

101 Por. M. LUBAŃSKI, Wprow'adzenie do informatyki, Warszawa 1979; tenże, Informacja - system, w: M. HELLER. M. LUBAŃSKI, S.W. ŚLAGA, Zagadnienia filozoficzne w'spótczesnej nauki, Warszawa 19822, 13-164; tenże. Człowiek, system, informacja, SPhCh 14/1978, 2/101144; tenże, Zagadnenia filozoficzne w' aspekcie systemowo-filozoficznym, RF 19/1981, 3/5-20.

112 Por. S.W. ŚlAGA, Ontologia systemow'a a filozofia przyrody, RF 30/1982, 3/119-128; tenże, z M. LUBAŃSKIM, Wspólnota kościelna w aspekcie systemon'ym, w: Czlowiek w'e 
poświęcone teoretycznym ujęciom współczesnej nauki w aspekcie systemowym i zastosowaniom tych ujęć do opisu i rozwiązań konkretnych problemów.

Naukę w stadium apragmatycznym ${ }^{103}$ można określić jako system twierdzeń (zdań) uporządkowanych logicznie, uzasadnionych, intersubiektywnie sprawdzalnych i komunikatywnych. Sformułowanie to wyraża tendencję $\mathrm{w}$ badaniach $\mathrm{z}$ zakresu filozofii nauki, znaną już od czasów Arystotelesa. S. Kamiński wyraża tę myśl w sposób następujący: „Wiedzę teoretyczną nazywa się na ogół poznaniem, które jest pod względem epistemologicznym i metodologicznym zaawansowane tudzież o charakterze wyjaśniającym, choćby w szerokim tego ostatniego terminu sensie. To zaawansowanie wiedzy ma miejsce wtedy, gdy jest ona specjalistyczna (zasadniczo ujmuje swój przedmiot w jednym aspekcie, czyli pod jednym kątem), empirycznie (przynajmniej genetycznie) lub racjonalnie uprawomocniona w sposób kontrolowany, treściowo i logicznie uporządkowana oraz wyrażona $w$ języku informatywnym (intersubiektywnie, czyli jednoznacznie, zrozumiałe przez fachowców)" ${ }^{\prime 104}$.

W naukowych badaniach systemowych uwzględnia się nie tylko aspekt przedmiotowy i metodologiczny, ale również aspekt społeczny, socjologiczny, wychowawczy, syntetyczny i dynamiczny.

Przypomnijmy z poprzedniego rozdziału pojeccie systemu, a mianowicie że jest on zespołem różnych elementów wzajemnie ze sobą powiązanych oraz na siebie oddziaływujących i stanowiących całość pod pewnym względem. W badaniach naukowych $\mathrm{z}$ zakresu sozologii wymagane jest podejście systemowe zarówno w aspekcie przedmiotowym, jak i metodologicznym. W badaniach tych wykorzystuje się wiele metod i technik w celu rozpoznania aktualnego stanu biosfery i antroposfery oraz ukazania konieczności zastosowania środków mających zahamować degradację środowiska naturalnego. Zbiór tych wszystkich metod i technik stanowi pewien system możliwości badawczych w sozologii.

Powyższe uwagi o problematyce metodologicznej sozologii ukazuja złożoność tej problematyki i postulują potrzebę bardziej analitycznego omówienia wszystkich czterech metod stosowanych w sozologii. Przedstawianie w sposób syntetyczny metod empirycznych, humanistycznych,

wspólnocie Kościota, pod red. L.Baltera, Warszawa 1979, 117-152; tenże, z M. LUBAŃSKIM, The System Approach to Scientific Research, PhI 5/1983, 1/1-13; tenże, U podstaw biosystemogenezy, w: W poszukin'aniu prawdy. Pamięci profesora Kazimierza Klósaka, pod red. M. Lubańskiego i S.W. Ślagi, Warszawa 1987, 174-201.

103 Por. AJDUKIEWICZ, Logika pragmatyczna, 177.

104 S. KAMIŃSKI, Typy wiedzy teoretycznej, AC 14/1982/11-12; por. tenże, O rozwoju teorii empirycznej, RF 30/1982, 3/129-142; tenże, O kryteriach wartościowania wiedzy teoretycznej, RF 30/1982, 2/125-130; Z. HAJDUK, O akceptacji teorii empirycznej, Lublin 1984. 
filozoficznych i systemowych jest zaledwie próbą całościowego ukazania metodologicznej problematyki sozologii, która jest ciągle aktualna i oczekuje na rozstrzygnięcia.

\section{Glówna problematyka sozologii systemowej i jej specyfika}

1. Główne problemy sozologii systemowej występują wokół następujących zagadnień:

- Stanu środowiska w Polsce, Unii Europejskiej i świecie;

- Źródeł zanieczyszczeń i zagrożeń środowiska przyrodniczego i społecznego;

- Wpływu zmieniającego się środowiska na życie na Ziemi oraz na życie i zdrowie człowieka;

- Środki i sposoby ochrony środowiska przyrodniczego i społecznego. Wszystkie te problemy i zagadnienia rozpatrywane są $w$ sozologii systemowej w następujących sferach, w których powstaje i rozwija się życie, a mianowicie:

- atmosfera;

- hydrosfera;

- litosfera;

- kosmosfera i magnetosfera;

- biosfera;

- antroposfera.

Wszystkie te sfery, w których występują różne formy życia, mają swoją strukturę $\mathrm{z}$ ustalonymi właściwościami warunkującymi funkcjonowanie tych form życia i również człowieka na Ziemi. W sozologii systemowej rozpatruje się stan tych sfer, zmiany zachodzące $w$ nich, wpływ na życie i zdrowie człowieka oraz szuka się sposobów i środków ochrony w wszystkich elementów środowiska.

2. Mając na względzie założenie jedności nauk, zwłaszcza jedność ich struktury logicznej, stosowanie w nich jednolitego systemu metod logicznych, które stanowią najtrwalszą cechę współczesnej nauki, oraz wpływ jednych badań na drugie $\mathrm{i}$ ich wzajemne zależności, ${ }^{105}$ staje się jasne, że

105 Por. B. PRANDECKA, Strategia ochrony środowiska - podstawy interdyscyplinarne, w: Ekonomiczne i socjologiczne problemy ochrony środon'iska, 9-20; F. RUSSELL, M. GARBUNY, H. HOOKE, Nauka o nauce. Metody objaśniania zjawisk fizycznych, thum. W. Lucjanek, Warszawa 1968, 13-30; E. NAGEL, Struktura nauki. Zagadnienia logiki wyjaśnień naukowych, tłum. pod red. B.Kuczyńskiej, Warszawa 1970, 7-9; T. CZEŻOWSKI, o jedności nauki, w: Fragmenty filozoficzne, seria 3, Warszawa 1967, 17-27; tenze, O zwiqzku między naukami aksjomatycznymi a naukami empirycznymi, SP 18/1973/11-18; S. KAMIŃSKI, Stosunek między poznaniem empirycznym a nieempirycznym w' nauce, w: Z zagadnień kultury chrzescijańskiej, Lublin 1973, 253-264. 
interdyscyplinarność jest nieodzowną cechą procesów naukowotwórczych sozologii i zarazem potwierdza suponowaną jedność nauk.

Naukowa problematyka sozologiczna sprawia, że badania interdyscyplinarne są w sozologii rzeczą konieczną. Jej rozwiązywanie bowiem wymaga współpracy $z$ następującymi naukami: ekologią, geologia, ekonomią, naukami technicznymi i technologicznymi, etyką i pedagogiką. ${ }^{106}$ Z tej współpracy między kształtującą się nauką, sozologią, a wymienionymi wyżej naukami rodzą się nowe dziedziny naukowe, takie jak sozotechnika, sozoekonomia, sozopsychologia, sozoetyka czy etyka ekologiczna, prawo ekologiczne czy sozologiczne, polityka ekologiczna ${ }^{107}$.

W ogólności można powiedzieć, że problematyka sozologiczna pojawia się w wielu naukach, ${ }^{108}$ a jej szczegółowe zagadnienia występują zwłaszcza w takich dyscyplinach jak: nauki medyczne, nauki biologiczne, nauki o ziemi i planowaniu przestrzennym, nauki techniczne, nauki ekonomiczne, nauki prawne i administracyjne, nauki społeczne i humanistyczne. Należy w tym miejscu dodać, że wobec sozologicznej problematyki naukowej nie moga pozostać obojętne ani kosmofilozofia, ani biofilozofia, ani antropofilozofia.

Badania z zakresu sozologii, jako nauki o systemowej ochronie biosfery przed destrukcyjnym oddziaływaniem na nią antroposfery, z konieczności się w niej problemy rozwiązywać wyczerpująco i wszechstronnie. Ponadto nauka ta ma charakter unifikujący badania $\mathrm{z}$ zakresu wielu dyscyplin naukowych. $\mathrm{Na}$ jej terenie moga powstawać teorie scalające osiągnięcia różnych nauk.

\section{Podsumowanie}

$\mathrm{W}$ opracowaniu tym zamieszczono notę $\mathrm{z}$ historii sozologii, podano charakterystykę koncepcji sozologii systemowej, przeprowadzono analizę podstawowych zagadnień z epistemologii i metodologii sozologii sys-

I'k Por. S. MYCZKOWSKI, Ochrona przyrody w' szkolnictwie i wychow'aniu, w: Ochrona przyrodniczego środowiska człowieka, 97-106; K. DUBEL, Edukacja ekologiczna jako w'arunek zrów'noważonego rozwoju w Polsce, III MSE 1-8; I. JARZYŃSKA, Ksztatcenie studentów' nauczania poczqtkow'ego w' zakresie ochrony środowiska przyrodniczego człowieka, III MSE 1-12; M. SZYREJ, Edukacja Środowiskowa prowadzona w' Wyzszej Szkole Pedagogicznej w' Częstochowie, III MSE 1-14; L. TOMCZYŃSKA, Aktywne nauczanie wspótpracy z przyrodq - potrzeby, wymagania, możliwości, III MSE 1-13.

107 Por. J. ALEKSANDROWICZ, P. WASZCZENKO, Środowisko w' perspektywie medycznej: humanizm ekologiczny szansq przetrwania, CŚZ 83-92; R.W. GUTT, Problem w'zorca lekarza i innychpracowników służby zdron'ia, CŚZ 468-476; ŚLIPKO, Granice życia, 22-70.

108 Por. Zadania nauki w dziedzinie racjonalnego ksztattowania środowiska cztonieka, red. wyd. J. Stępień, Wroclaw 1974, 40-88. 
temowej oraz zaprezentowano główne i specyficzne problemy sozologii systemowej. Prowadzone badania naukowe $\mathrm{w}$ tej problematyce $\mathrm{w}$ dalszym ciągu wymagają współpracy z metodologami i logikami w celu dopracowania epistemologii i metodologii sozologii systemowej. Współpraca ta powinna uwzględnić również historię zagadnień sozologicznych $\mathrm{w}$ zakresie ogólnopolskim i międzynarodowym.

\section{The Philosophy of Systematic Sozology}

\section{SUMMARY}

The philosophy of systematic sozology presented in this work has as itscharacteristic originality under two aspects: metaobjective and objective.

In the metaobjective aspect, here called the philosophy of sozology, one should underline the following elements:

- the elaboration of the notion - enviroment,

- the determining of the contents of the expression: social-natural enviroment,

- the elaboration of the definition of systematic sozology,

- the definition of the object of research of this discipline of science,

- the presenttation of the structure, and especially the underlining of the importance of: interdisciplinarity, transdisciplinarity, systemtics and globalism in the methodology of systematic sozology.

In the objective or essential aspect the originality of the work is the underlining of the basic issuses of systematic sozology and the presentation of them in six spheres, in which the process of life is realized, thet it:

- the state of the social-natural environment,

- the sources of endangerment and of pollution of the environment, the influence of the changing environment to life on Earth,

- the ways and means of protecting the environment. 